\title{
Nutrigenomics of Dietary Lipids
}

\author{
Laura Bordoni ${ }^{1}{ }^{\circledR}$, Irene Petracci ${ }^{2}$, Fanrui Zhao ${ }^{2,3}$, Weihong Min ${ }^{3}$, Elisa Pierella ${ }^{4}\left(\mathbb{D}\right.$, Taís Silveira Assmann ${ }^{5} \mathbb{D}^{\circ}$, \\ J Alfredo Martinez ${ }^{6,+}$ (i) and Rosita Gabbianelli ${ }^{1, *,+}$ (i)
}

1 Unit of Molecular Biology and Nutrigenomics, School of Pharmacy, University of Camerino, 62032 Camerino, Italy; laura.bordoni@unicam.it

2 School of Advanced Studies, University of Camerino, 62032 Camerino, Italy; irene.petracci@unicam.it (I.P.); fanrui.zhao@unicam.it (F.Z.)

3 College of Food Science and Engineering, Jilin Agricultural University, Changchun 130118, China; minwh2000@jlau.edu.cn

4 School of Medicine, Faculty of Clinical and Biomedical Sciences, University of Central, Lancashire, Preston PR1 2HE, UK; EPierella1@uclan.ac.uk

5 Postgraduate Program in Medical Sciences: Endocrinology, Faculty of Medicine, Federal University of Rio Grande do Sul, Porto Alegre 90035093, Brazil; taisassmann@hotmail.com

6 CIBERobn Fisiopatología de la Obesidad, Instituto Carlos III, Precision Nutrition Program IMDEA Food UAM-CSIC, 28049 Madrid, Spain; jalfmtz@unav.es

* Correspondence: rosita.gabbianelli@unicam.it; Tel.: +39-0737-403208

+ Equal senior coauthor.

check for updates

Citation: Bordoni, L.; Petracci, I.; Zhao, F.; Min, W.; Pierella, E.; Assmann, T.S.; Martinez, J.A.; Gabbianelli, R. Nutrigenomics of Dietary Lipids. Antioxidants 2021, 10, 994. https://doi.org/10.3390/ antiox10070994

Academic Editor: Fiorella Biasi

Received: 10 May 2021

Accepted: 16 June 2021

Published: 22 June 2021

Publisher's Note: MDPI stays neutral with regard to jurisdictional claims in published maps and institutional affiliations.

Copyright: (c) 2021 by the authors. Licensee MDPI, Basel, Switzerland. This article is an open access article distributed under the terms and conditions of the Creative Commons Attribution (CC BY) license (https:/ / creativecommons.org/licenses/by/ $4.0 /)$.

\begin{abstract}
Dietary lipids have a major role in nutrition, not only for their fuel value, but also as essential and bioactive nutrients. This narrative review aims to describe the current evidence on nutrigenomic effects of dietary lipids. Firstly, the different chemical and biological properties of fatty acids contained both in plant- and animal-based food are illustrated. A description of lipid bioavailability, bioaccessibility, and lipotoxicity is provided, together with an overview of the modulatory role of lipids as pro- or anti-inflammatory agents. Current findings concerning the metabolic impact of lipids on gene expression, epigenome, and gut microbiome in animal and human studies are summarized. Finally, the effect of the individual's genetic make-up on lipid metabolism is described. The main goal is to provide an overview about the interaction between dietary lipids and the genome, by identifying and discussing recent scientific evidence, recognizing strengths and weaknesses, to address future investigations and fill the gaps in the current knowledge on metabolic impact of dietary fats on health.
\end{abstract}

Keywords: nutrigenomics; fatty acids; inflammation; gut microbiota; personalized nutrition

\section{Introduction}

Diet is one of the most important environmental factors able to maintain health and prevent diseases, starting from early neonatal life with a myriad of nutritional properties, affecting energy supply, regulatory functions, and structural roles [1,2]. During recent last years, omics approaches, including genetics, epigenetics, and gut microbiome analyses, have been introduced in nutrition research, providing a comprehensive picture able to renovate molecular nutrition studies toward an advanced and systemic vision. Food has been studied not only from a chemical prospective, but also for the capacity of metabolites produced by food oxidation to modulate gene expression, directly (nutrigenomics) or by epigenetics remodeling (nutri-epigenomics) [3]. However, inter-individual differences (i.e., the genetic variability) and environmental exposures (i.e., physical activity, drug, food pesticide residues, etc.) contribute to produce a plethora of multifaceted effects [4]. For these reasons, understanding molecular effects of food on human health is an ambitious but promising goal, which could strongly impact dietary choices considering not only food composition, but also its nutrigenomic and nutri-epigenomic properties. 
In particular, one of the aims of nutrition research is to control systemic chronic inflammation (SCI), that negatively affects human health [5]. Since, SCI can increase the risk of developing several diseases (i.e., metabolic syndrome, cardiovascular disease, neurodegeneration, cancer, etc.), one major focus of nutrigenomics is to identify those foods or food-derived metabolites that can modulate pro and anti-inflammatory genes expression. In this context, dietary lipids can exert both pro- and anti-inflammatory effects, according to their chemistry. Unfortunately, consumers' dietary unhealthy habits frequently results in a poor nutrition rich in ultra-processed food intake. However, we have a partial knowledge of the composition of the food we daily eat [6], and of the impact that food can have on our individual genome, several findings about nutrigenomic properties of dietary lipids from both humans and animal models have been collected.

In this milieu, the objectives of the present narrative review are framed as follows: (1) describe the lipid content in plant and animal-based food products; (2) outline the molecular mechanisms associated to the pro- and anti-inflammatory responses of dietary fatty acids; (3) summarize the main findings on nutrigenomics of dietary lipids acquired from animal and human studies; (4) explain the mechanisms implicating dietary lipids in the modulation of the gut microbiota compositions and metabolites production; (5) discuss the main impact of dietary lipids on human health.

The search strategy includes the terms "nutrigenomics AND dietary lipids" or "fats AND animal-based food products" or "fats AND plant-based food products" or "fatty acids AND inflammation" or "fatty acids AND human health" or "dietary lipids AND gut microbiota" or "fats AND gut metabolites" as keywords. The search has been performed in the NCBI-PubMed database. The records have been screened for relevant information and only papers published within the period 2010-2020 have been selected and studied.

\section{Dietary Lipids: Fatty Acids in Plant- and Animal-Based Food Products}

Dietary lipids' main roles are to supply energy, provide essential fatty acids, guarantee the required lipids for cellular structures (i.e., membranes), regulate signaling systems, and ease the absorption of fat-soluble vitamins (A, D, E and K). According to their physicochemical structure, dietary lipids exert a different nutrigenomic impact, modulating the expression of genes involved in the control of inflammation, blood pressure, lipid metabolism, and other metabolic responses [7-9].

Dietary lipids comprise fatty acids (FAs) and cholesterol. FAs can be free (i.e., butter, oils, milk) or esterified in food to form triacylglycerols and other complex lipids (i.e., phospholipids, glycolipids, and glycoproteins). FAs differ for the length of the carbon chains, which influence the intimate physicochemical properties, and for the absence or the presence of one or more double bonds; based on this second feature, three main classes exist: (i) saturated FAs (SFAs), such as palmitic acid, myristic acid, and lauric acid; (ii) monounsaturated FAs (MUFAs), such as $\omega-9$ oleic acid (OA); (iii) polyunsaturated FAs (PUFAs) (Figure 1). PUFAs include two essential groups, omega-3 (or n-3 or $\omega-3$ ) and omega-6 (or n-6 or $\omega-6$ ) FAs, which have to be obtained through the diet because they cannot be synthetized by human enzymes. Among $\omega-3$ FAs, linolenic acid (ALA; 18:3 $\omega-3$ ) is mostly contained in plants (i.e., flaxseed, canola, soybean, nuts, walnuts, chia seeds, etc.), while eicosapentaenoic acid (EPA; 20:5 $\omega$-3) and docosahexaenoic acid (DHA; 22:6 $\omega-3)$ are present mostly in fish, seafood, and marine algae. Among $\omega-6$ FAs, linoleic acid (LA; 18:2 $\omega-6$ ) is provided by seed oils, soybean, nuts, and cereals, while arachidonic acid (ARA; 20:4 $\omega-6)$ is found in poultry and eggs [10]. Land-based food chain is dominated by higher LA than ALA; these two essential FAs give rise to $\omega-6$ and $\omega-3$ series, which have a different impact on the inflammatory response. 


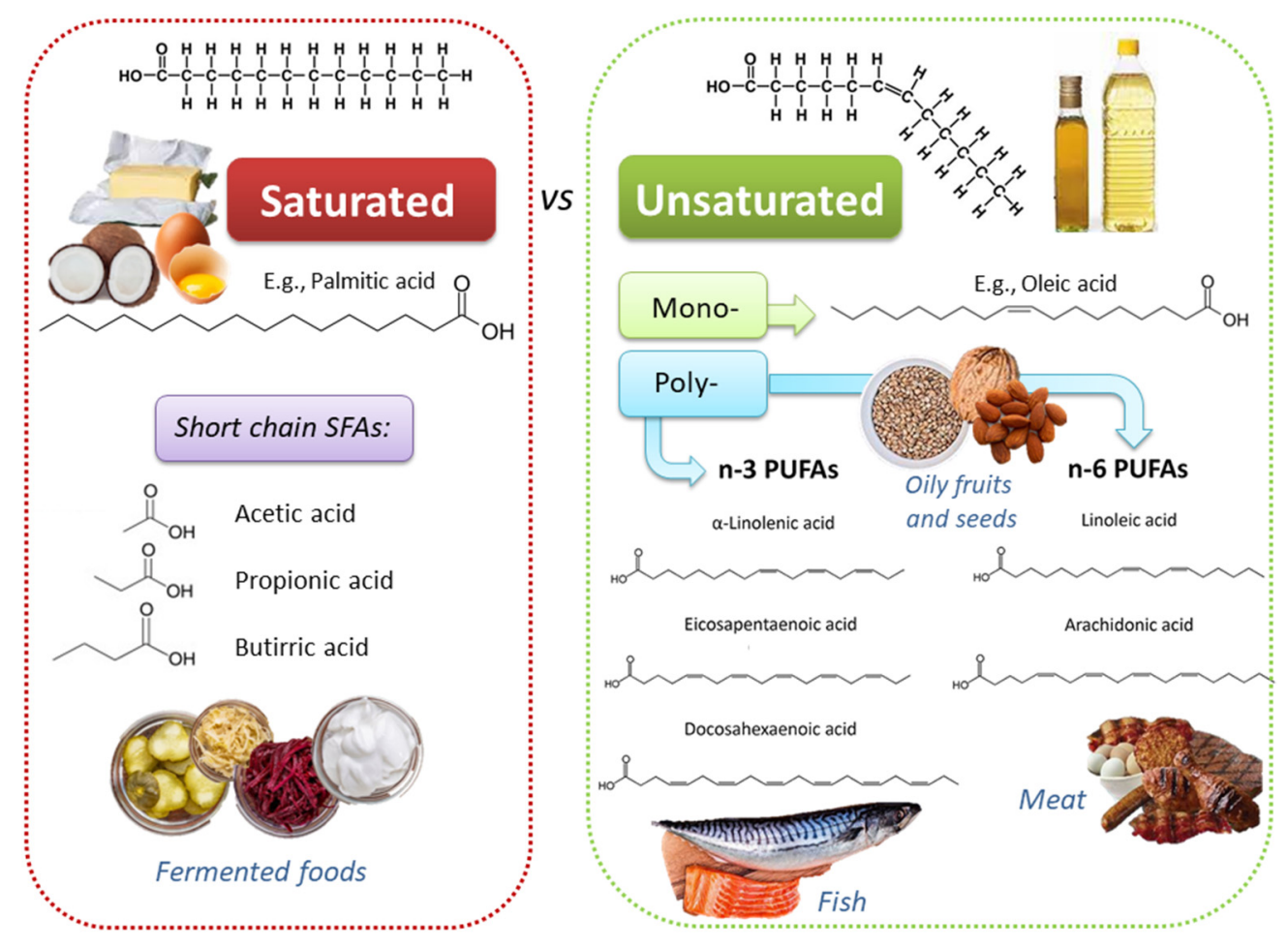

Figure 1. Chemically diverse lipid sources, with heterogeneous physico-chemical and biological properties, can be found in different foods.

Various SFAs are supplied by both animal- (i.e., meat, seafood, milk, cheese, eggs, etc.) and plant-based food (i.e., oilseeds, olives, avocados, walnuts, etc.). Meat content in SFAs depends on animal species, growth, and environmental conditions; generally, SFAs content decreases going from beef $(6.2 \mathrm{~g} / 100 \mathrm{~g})$ to pork $(5.4 \mathrm{~g} / 100 \mathrm{~g})$ and to chicken breast $(1.4 \mathrm{~g} / 100 \mathrm{~g})$ [11]. Meat content in MUFAs (i.e., $\omega-3)$ is very low $(0.1-0.2 \mathrm{~g} / 100 \mathrm{~g})$, while the $\omega-6$ LA is $2.9,3.2$, and $0.8(\mathrm{~g} / 100 \mathrm{~g})$ in beef, pork, and chicken breast, respectively [11]. However, feed background of ruminants (i.e., forage- or grass-fed containing high amount of ALA) significantly contributes to increase the concentration of $\omega-3$ FAs in red meat [12]. Among animal-based food products, whole milk is rich in SFAs $(2.2 \mathrm{~g} / 100 \mathrm{~g})$, whose content decreases in skimmed milk $(0.1 \mathrm{~g} / 100 \mathrm{~g})$. Butter is an animal fat containing a large amount of SFAs (52.9 g/100 g) and cholesterol $(227 \mathrm{mg} / 100 \mathrm{~g})$ [11,13]; margarine, obtained from partially hydrogenated vegetable oils, includes less SFAs $(8.5 \mathrm{~g} / 100 \mathrm{~g})$ than butter, but it is rich in trans-FAs, which increase the risk to develop cardiovascular and neuronal disorders [14-16].

Among the most commonly used edible oils, coconut oil (CO) contains the highest SFAs content (81.2-94\%), followed by palm oil (PO) (49.7-57.5\%), soybean oil (6.0-24.0\%), olive oil (12.5-20.9\%), corn oil (15-16\%), walnut oil (5-17\%), and sunflower oil (9-13\%) [17]. The content in the OA, an $\omega-9$ MUFAs, (which exerts anti-inflammatory properties and improve blood pressure [18-21]) decreases form olive oil (54.5-80.2\%), to PO (37.3-40.8\%), corn oil (27.6-34.6\%), soybean oil (15-36\%), sunflower oil (16.4-27.6\%, walnut oil (10-20\%) and CO $(5-10 \%)$. LA concentration increases starting from coconut oil $(1-2.5 \%)$, to PA (9.1-11\%), olive oil (4.9-21.2\%), corn oil (48.8-55.3\%), soybean oil (42.8-56.1\%), walnut oil $(55-70 \%)$, and sunflower oil $(60.2-72.1 \%)$. ALA content decreases from walnut oil (10-18\%) to soybean oil (2-14\%), CO (0.2-2.5\%), sunflower oil ( $0.07-1.8 \%)$, olive oil $(0.7-1.5 \%)$, corn oil (0.6-1.49\%), and PA (0.01-0.25\%) [17].

Other aspects should be considered in the evaluation of the nutrigenomic properties of plant- and animal-based fats: (i) the presence of bioactive compounds that contribute to modulate gene expression; (ii) the oil oxidative stability. For example, olive oil contains a large number of bioactive substances, such as polar phenolic substances (i.e., hydroxy- 
tyrosol and derivatives like oleuropein complex, tyrosol) and $\alpha$-tocopherol, which plays a key role in the health promotion and oil stability [22]. Another example is the thymoquinone, contained in Nigella sativa oil, which contributes to modulate the noteworthy anti-inflammatory properties of this oil, which resulted to be quite similar to olive oil in low-grade inflammation models [23-25]. To increase their healthy properties, some foods have been also fortified with $\omega-3$ PUFAs (i.e., egg sticks, hen eggs, dahi, chicken-meat, milk, etc.) [26-30]. Moreover, research has identified also other kinds of vegetable oils that could represent a suitable source of healthy lipids. These includes oils derived from cucumber, tomato, pumpkin or carrot seeds, which contain different profiles of FAs; for instance, OA is largely contained in carrot seed oil (78.97 g/100 g of total FAs) [31].

Another significant aspect to consider is the oxidative status of oils and of the other dietary lipids, which depends on their unsaturated FAs content (i.e., the presence of double bonds is associated to a faster oxidation rate). For example, LA, which has two double bonds, shows an oxidation rate ten times higher than OA, which has only one double bond [32]. Hydroperoxides and malondialdehyde (MDA) can be produced during technological processing, light exposure, oxygen, and temperature storage, as well as due to cooking; lipid oxidation decreases the quality of dietary FAs and their chemical, sensory and structural properties (i.e., membrane phospholipids) [33-35]. For all these reasons, vegetal- and animal-based food should be evaluated also considering both intrinsic components (i.e., FAs composition, antioxidants, water, etc.) and external factors (i.e., light, temperature, oxygen), which contribute to preserve their original naïve composition. For example, the high quality of olive oil, with a lower oxidative index in respect to others [32], depends on the high concentration of MUFAs and the low PUFAs content; this is an additional value over and above the bioactive substances contained in the unsaponifiable fraction, which also has a well-balanced saponifiable fraction, rich in OA and poor in SFAs.

Considering the metabolic and functional roles of dietary lipids, from 20 to $35 \%$ of the total energy should be obtained from fat. For each type of fat, the recommendations are as follows: SFAs $<10 \%$, PUFAs $5-10 \%$, of which $\omega-6$ PUFAs $4-8 \%$ and $\omega-3$ PUFAs $0.5-2 \%$, trans-FAs $<1 \%$ and cholesterol $<300 \mathrm{mg}$, according to accepted dietary recommendations [36].

In summary, plant- and animal-based foods contribute to modulate molecular responses according to their chemical composition and stability; whether prefer plant- or animal-based food has been the object of study for a long time, and research on large cohorts of middle-age adults supports the positive impact of a higher adherence to a plantbased diet due to the presence of bioactive compounds able to reduce the risk of mortality (i.e., cardiovascular disease mortality $(-19 \%)$, all-cause mortality $(-11 \%)$ ) [37]. Multiple studies in different models (i.e., cell lines, preclinical and human studies) have provided a wealth of information on the molecular basis of dietary lipids' impact on gene expression. Henceforth, the following sections describe these data in order to give a comprehensive picture of the nutrigenomic impact of dietary lipids.

\section{Dietary Lipids Bioavailability, Bioaccessibility, and Toxicity}

As well as for other bioactive food compounds, the nutritional effect of lipids depends on their release in the gastrointestinal tract, intestinal absorption, and metabolism (i.e., their bioaccessibility and bioavailability). Lipids bioavailability refers to the fraction of the ingested lipids that eventually reaches the systemic circulation, to be later distributed to tissues and organs, where it may be either stored, utilized, or excreted. However, not the whole lipid cargo of a meal is bioavailable to exert a biological function. Indeed, only the bio-accessible lipid fraction, which is the one released from the food matrix, is available for intestinal absorption. Hence, for lipids, the possibility to exert a biological effect is strictly dependent on their bio-accessibility (Figure 2) [38]. 


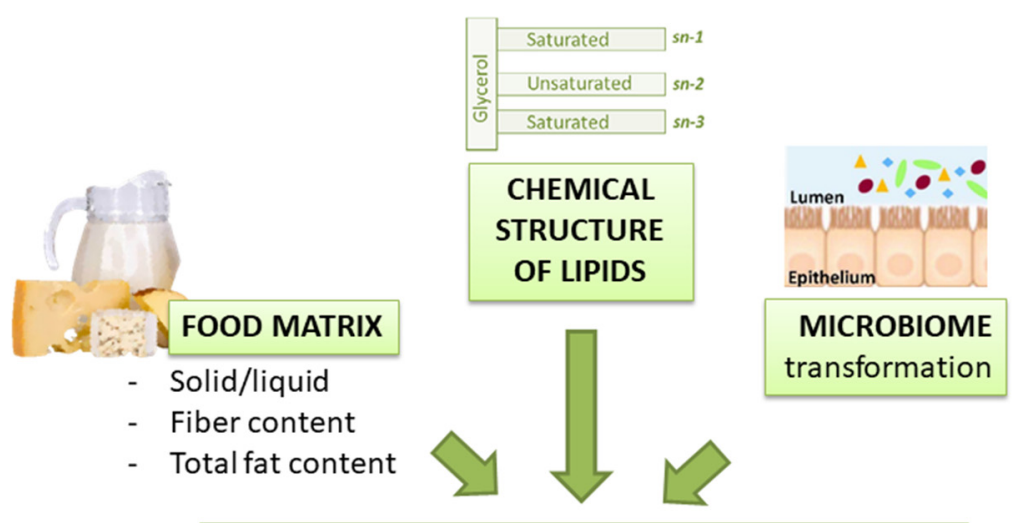

BIOAVAILABILITY AND BIOACCESIBILITY

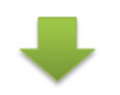

\section{NUTRIGENOMIC PROPERTIES OF LIPIDS}

\section{LIPOTOXICITY}

- Lipid peroxidation

- SFA accumulation

Figure 2. Dietary lipids bioavailability, bioaccessibility, and lipotoxicity contribute to their nutrigenomic properties.

The interaction between dietary fats and the food matrix (i.e., food composition) is very important to guarantee their accessibility, digestibility, and bioavailability. MartínezRamírez et al. described how the digestibility of FAs is influenced by lipid source and content of a meal, dietary fibers, host animals, and other molecules (e.g., mucilage and cyanogenic glycosides in flaxseed) [39]. For instance, it is well documented that the digestibility of lipids inversely correlates with the dietary fiber content of a meal [40]. Also, the total fat content of a meal can modulate the bioavailability of dietary FAs, mainly through the stimulation of pancreatic juice secretion and the activation of pancreatic lipases, which makes dietary FAs more accessible. The role of the meal fat content is especially crucial for essential $\omega-3$ PUFAs, in particular for dietary ALA, whose conversion rate into physiologically active EPA and DHA is very limited: even though data from literature may slightly differ, approximately 5\% of ALA is converted to EPA and less than $0.5 \%$ to DHA [41]. Moreover, it was already known that the conversion rate is dependent on certain physiological states and on the concentration of $\omega-6$ PUFAs or other fats [42]. In particular, previous evidence suggested that with a background diet rich in saturated fats, the conversion of ALA to EPA is around 6\%, while approximately 3.8\% ALA is converted to DHA. Instead, with a background diet rich in $\omega-6$ PUFAs, this conversion decreases by 40 to $50 \%$ [43]. However, ALA conversion seems to be unaffected by the $\omega-6 / \omega-3$ ratio, and being dependent only on their absolute amounts in the diet [42]. Lawson and Hughes showed that $\omega$-3 PUFAs absorption rate can be increased three-fold when co-ingested with a high-fat meal relative to a low-fat meal [44,45]. Interestingly, the ECLIPSE studies [Epanova ${ }^{\circledR}$ Compared to Lovaza ${ }^{\circledR}$ In a Pharmacokinetic, Single-dose, Evaluation] have proved that a novel free FAs (FFAs) formulation for $\omega$-3 supplements (OM-3 FFA) exhibits a 4-fold greater bioavailability in overweight patients either in a single dose $(4 \mathrm{~g})[46,47]$ or over a two-week period under low-fat dietary intake [48]. This might help in subjects with 
hypertriglyceridemia that need to maximize the intestinal absorption of EPA and DHA, while maintaining their total dietary fat intake low.

Several studies proved that not only the composition, but also the structure (solid or liquid) of the food matrix is an important modulator of dietary fats accessibility. An in vitro study on microencapsulated tuna oil showed that either the way of ingestion or the chemical formulation strongly affect the release of EPA and DHA from tuna oil during digestion [49]. In vitro digestion of tuna oil in the form of neat microencapsulated tuna oil powder (25\% oil loading) or in food matrices (orange juice, yogurt, or cereal bar) fortified with microencapsulated tuna oil powder (fortification was equivalent to $1 \mathrm{~g}$ of tuna oil per recommended serving size), showed that the percentage of EPA and DHA released from tuna oil was greater (73.2-78.6\%) for neat powder, fortified orange juice, and yogurt compared to the fortified cereal bar (60.3-64.0\%), proving that the food matrix, its structure (e.g., solid versus liquid), and its composition (greater fiber content of the cereal bar) may affect in vitro digestion of microencapsulated tuna oil powder [49]. An in vivo study, based on three matrices having the same composition but different structures (DHAenriched egg in the form of omelet, hard-boiled egg, and mousse) found that the egg in the form of omelet was the most efficient vector for delivering DHA into systemic circulation $(33.3 \pm 3.6 \mu \mathrm{g} / \mathrm{mL}$ and $17.9 \pm 3.7 \mu \mathrm{g} / \mathrm{mL}$ at 10 and $24 \mathrm{~h}$ after feeding, respectively), further stressing the impact of food matrix structure on DHA bioavailability [50]. Lastly, differently structured food products can lead to different profiles of postprandial lipemia. For example, for dairy products, Lamothe et al. showed that the fatty acid release in the intestinal phase is faster when the cheese matrix derives from homogenized milk [51]. Also, the cheese's composition, viscosity, and structure (more or less solid) have an impact on the kinetics of digestion of the lipids from cheeses and can affect the peak of postprandial triglyceridemia [52]. Specifically, the denser and more cohesive the cheese matrix structure, the lower the rate gastric digestion of lipids [53].

In addition, several human studies have focused on the role of the chemical structures of lipids on Fas bioavailability [44]. Over $90 \%$ of dietary lipids are esterified to triacylglycerol (TAGs), but they can only be absorbed when released from the TAGs as non-esterified FAs (FFAs) or as 2-monoacylglycerols (2-MAGs) after digestive lipolysis [54]. The rate at which FAs are released from TAGs during lipolysis inversely correlates with their chain length, and also depends on their intramolecular structure on the glycerol backbone (internal sn-2 position, external sn-1 and sn-3 positions). Thus, digestive lipases preferentially hydrolyse FAs esterified on sn-1,3 positions of glycerol backbone, but when TAGs contain long-chain FAs in these positions, their hydrolytic activity decreases. For instance, long-chain saturated FAs, such as palmitic acid and stearic acid, are mainly bound in the sn- 1 and sn-3 positions of TAGs, but exhibit poor bioavailability because they tend to form complexes in presence of divalent ions $\left(\mathrm{Ca}^{2+}\right.$ and $\left.\mathrm{Mg}^{2+}\right)$, resulting in the formation of insoluble soaps in the small intestine that can be lost in the stools [54,55]. Instead, when PUFAs are esterified in the sn- 1 and sn-3 positions of TAGs with double bonds close to the carboxyl group, the hydrolytic activity of lipases decreases because of steric hindrance problems, with an impact on PUFAs bioavailability [54]. Conversely, PUFAs esterified at the sn-2 position of TAGs appear to be more efficiently absorbed. For example, supplementation of human adults with fish oil, which has DHA mostly on sn-2 position and EPA on the sn- 1 and sn-3 positions, resulted in more rapid incorporation of DHA in plasma TAGs than EPA [56]. Coherently, a six-month supplementation of identical doses of EPA+DHA resulted in a faster and higher increase in the $\omega-3$ index (i.e., the percentage of EPA+DHA in red blood cell membranes) when consumed in the form of triacylglycerides than as ethyl esters (EEs) [57]. Studies on the kinetics of $\omega-3$ PUFAs confirmed the following trend for bioavailability: FFAs > TAGs > diacylglycerol (DAGs) $\backslash$ MAGs > EEs [58-60], although recent findings [61] question the previously stated greater bioavailability of TAGs compared to EEs [62], while information on the bioavailability of $\omega-3$ PUFAs esterified to phospholipids is so far poor and inconclusive $[63,64]$. 
Lastly, PUFAs' bioavailability and transformation can be also affected by the gut microbiota. In fact, some microbial species, such as Butyrivibrio fbrisolvens, Clostridium proteoclasticum, or Lactobacillus plantarum play a crucial rule in the transformation of $\omega-6 \backslash \omega$ 3 PUFAs into conjugated FAs that may further undergo hydrogenation to saturated FAs, reducing the amount of the bioavailable unsaturated fraction [65].

In addition to bioavailability, another aspect to mention before discussing the molecular effects of lipids is lipotoxicity. Lipotoxicity arises as a consequence of the accumulation of biosynthetic lipid intermediates, such as ceramides and diglycerides, within non-adipose tissues, and induces endoplasmic reticulum stress, inflammation, mitochondrial dysfunction, and ultimately apoptosis [66]. Pancreatic $\beta$-cells are among the most affected cells, whose impaired insulin secretion results in the development of insulin resistance, T2DM or other obesity-related pathologies, such as cardiovascular diseases and the metabolic syndrome [67-70]. Lipotoxicity may also affect other organs, such as kidney, liver, heart and skeletal muscle, and clinical manifestations are renal dysfunction, anemia, heart failure, and sarcopenia [71]. To mitigate the detrimental effects of ectopic lipid accumulation, lipid-lowering drugs supported by suitable dietary changes may be valid tools. In this regard, recent studies have shown that soy proteins and soy isoflavones are able to decrease lipotoxicity by modulating insulin secretion and lowering ceramides accumulation [72,73]. Another mechanism by which lipid imbalance turns out to be toxic is lipid peroxidation. Lipid peroxides are highly reactive compounds, which trigger many pathological states including inflammation, cancer, neurodegenerative disease, as well as ocular and kidney degeneration. They result from enzymatic (cyclooxygenase (COX), cytochrome P450 (CYP), and lipoxygenase (LOX)) and non-enzymatic ("Fenton Chemistry") peroxidation reactions of lipids, preferentially PUFAs. Lipid peroxides not only alter the assembly, composition, structure, and dynamics of cell membranes, but can exhibit additional toxicity with their degradation products: hydroxy acids and reactive aldehydes, like and 4-hydroxynonenal (4$\mathrm{HNE}$ ) and MDA, are able to propagate further generation of reactive oxygen species (ROS) or crosslink DNA and proteins, resulting in multiple pathologies and cell death [74-77].

To conclude, Fas bioavailability, bioaccessibility and toxicity contribute to determine their role as regulatory and bioactive molecules.

\section{Crosstalk between Fatty Acids and Inflammation}

FAs, synthesized or metabolized from dietary sources, serve mainly as structural components of cells and energy substrates; however, increasing evidence have demonstrated an important role as mediators of inflammation, with downstream effects depending on their nature [78,79]. The effect of FAs on inflammatory responses derives from their incorporation into cell membrane phospholipids. Different lipid mediators may be generated from phospholipids, which can boost or fight against inflammation. Based on that, lipid mediators deriving from $\omega-6$ PUFAs are considered pro-inflammatory and are associated with the pathogenesis of inflammatory processes [80]. A direct link with inflammation is provided by LA, a common dietary $\omega-6$ PUFAs. LA can be converted to ARA, a major component of membranes phospholipids, which acts as a substrate for COX, LOX, and CYP enzymes to yield eicosanoid mediators, such as hydroperoxyeicosatetraenoic acid (HPETE), prostaglandins (PGs), thromboxanes (TXs), leukotrienes (LTs), and lipoxins. Given its abundance in cell membranes, ARA is the major substrate for eicosanoids production, which explains why it is considered proinflammatory. Eicosanoids are oxidized lipid derivatives, which control initiation, magnitude, and duration of inflammation, acting usually via G protein-coupled receptors (GPCRs) [81]. However, not all eicosanoids have pro-inflammatory effects, such as those derived from $\omega$-3 PUFAs [82]. In this regard, EPA and DHA, resulting from chemical modifications of ALA, the major representative of $\omega-3$ PUFAs, give rise to eicosanoids with primarily anti-inflammatory or pro-resolving functions [82]. Because of structural differences compared to those derived from ARA, EPA-derived eicosanoids bind with lower affinity to eicosanoid receptors resulting in a weaker inflammatory response [83]. Moreover, EPA and DHA give rise to pro-resolving 
eicosanoid mediators, the so-called resolvins, protectins, and maresins, which accelerate the resolution of inflammation $[84,85]$, inhibiting immune cells migration, matrix metalloproteinases synthesis, and the release of inflammatory cytokines, like interleukine (IL)- $1 \alpha$, IL-1 $\beta$, IL-6, IL-8, IL-12, tumor necrosis factor $\alpha$ (TNF $\alpha)$, interferon $\gamma($ IFN $\gamma)$, and many more [83]. The main mechanism by which $\omega-3$ PUFAs block the cytokines storm is through the suppression of the nuclear factor kappa B (NF- $\kappa B$ ) inflammatory signaling [86] NF- $\kappa B$ impairment is firstly mediated by the activation of the peroxisome proliferator-activated receptor $\gamma($ PPAR- $\gamma)$, a transcription factor that physically interferes with NF- $\mathrm{kB}$ translocation to the nucleus, preventing pro-inflammatory cytokines release [87]. Moreover, $\omega-3$ PUFAs prevent the activation of Toll-like receptors (TLRs), in particular TLR4, which is the starting point for NF- $\mathrm{KB}$ activation and, lastly, they initiate an anti-inflammatory signaling cascade by binding to GPR40 and GPR120 [88-90]. The different effects of dietary $\omega-6$ and $\omega-3$ PUFAs on the inflammatory cascade shed light on the importance of keeping a low $\omega-6 / \omega-3$ ratio (4:1), in order to prevent or mitigate inflammatory-based pathologies, such as obesity, T2DM, arthritis, and others [91-93].

Anti-inflammatory properties have also been attributed to MUFAs [94]. MUFAs, such as oleic acid or palmitoleate, inhibit the formation of nucleotide-binding and oligomerization domain-like receptor, leucine-rich repeat, and pyrin domain-containing 3 (NLRP3) inflammasome, which is important for the production of mature inflammatory cytokines (i.e., IL-1 $\beta$ and IL-18) [7]; moreover, they maintain 5'AMP-activated protein kinase (AMPK) activity, which reduces the inflammatory response [95]. As PUFAs, MUFAs do not seem to activate TLR4 signaling [96], which instead, is one of the main mechanisms by which SFAs promote inflammation. Indeed, a proinflammatory effect has been attributed to SFAs, especially lauric acid, because of their effect on TLR2 and TLR4 signaling pathways $[96,97]$. SFAs trigger the dimerization and translocation of TLR2 or TLR4 into lipid rafts of plasma membranes, activating downstream signal transduction pathways in monocytes/macrophages, adipocytes, skeletal muscle cells, and pancreatic $\beta$ cells $[97,98]$. Upon interaction with TLRs, SFAs activate the myeloid differentiation primary response 88 (MyD88)-dependent signaling cascade, culminating with the activation of the two major inflammation-related signaling routes in cells, NF- $\mathrm{KB}$ and mitogen-activated protein kinase (MAPK) pathways [97]. Both result in increased expression and release of pro-inflammatory cytokines and chemokines. These mediators induce local or systemic inflammation, also helped by the massive release of ROS upon activation of nicotinamide adenine dinucleotide phosphate (NADPH) oxidase [99]. The signaling cascade activated by ROS and other stress molecules, like ATP and ceramides, leads to the assembly of the NLRP3 inflammasome, with the subsequent release of inflammatory cytokines [100,101], which, on the contrary, is counteracted by dietary MUFAs and $\omega-3$ PUFAs $[7,102]$. In addition, SFAs may also induce the release of inflammatory cytokines in a MyD88-independent manner, via the activation and nuclear translocation of interferon regulatory factor 3 (IRF3), or reinforcing NF- $k B$ activation [97].

However, SFAs must not be demonized in toto. A subset of SFAs, the so-called short chain fatty acids (SCFAs) are known for their positive regulatory effect on the immune responses. SCFAs are the end products of anaerobic fermentation of dietary fiber and resistant starches by colonic bacteria strains, with the main members being acetate, propionate, and butyrate. Recent evidence shows that SCFAs play an anti-inflammatory role through GPCRs, in particular GPR41 and GPR43, and via inhibition of histone deacetylases (HDACs) [103]. The binding of SCFAs to GPCRs prevents NF-KB activation [104] and up-regulates the expression of anti-inflammatory IL-10 via HDAC inhibition [105-107]. Although SCFAs anti-inflammatory role appears evident, some studies have found that the same pathway mediated by GPCRs may also trigger SCFAs-induced pro-inflammatory responses [108,109].

Moreover, other experimental studies have demonstrated that the effect of lipids can be modulated by other dietary components. For example, a diet containing SFAs 
supplemented with polyphenols (i.e., epigallocatechin gallate, resveratrol) shows a reduced pro-inflammatory response [110-112].

Remarkably, it has been found that the deficiency of NLRP3 inflammasome reduces the negative impact of a high fat diet (HFD) also through changes in the gut microbiota composition, supporting a pivotal role of this pathway in regulating the effect of fatty acids on inflammation also through the microbiome (see Section 6 for details) [113].

In conclusion, FAs exposure and FAs composition of cellular membranes profoundly influence cellular functions, but the final effect is complex and is the resultant of the whole composition of the diet. Overall, the types of FAs consumed with diet are of pivotal importance for the modulation of inflammatory processes via the activation or repression of key intracellular signaling pathways, with MUFAs, $\omega-3$ PUFAs, and SCFAs mainly triggering anti-inflammatory responses, and SFAs or $\omega-6$ PUFAs leading towards a proinflammatory state (Table 1 ).

Table 1. Major molecular mechanisms explaining the dietary FAs modulation of the inflammatory response.

\begin{tabular}{|c|c|c|c|c|}
\hline Fatty Acids & Pro-Inflammatory Effect & Anti-Inflammatory Effect & Other Effects & References \\
\hline \multirow{10}{*}{ SFAs } & TLR2/TLR4 signaling pathways & & & [96-98] \\
\hline & MyD88-dependent NF- $\kappa B$ and & & & \\
\hline & MAPK activation & & & \\
\hline & IL- $1 \alpha$, IL-1 $\beta$, IL-6, IL-8, IL-12, & & & [97] \\
\hline & $\mathrm{TNF} \alpha, \mathrm{IFN} \gamma$ release & & & \\
\hline & MyD88-independent IRF3, and & & & \\
\hline & $N F-k B$ activation & & & \\
\hline & NADPH oxidase activation and & & & [99] \\
\hline & ROS release & & & \\
\hline & $\begin{array}{l}\text { NLRP3 inflammasome assembly } \\
\text { and activation }\end{array}$ & & & {$[100,101]$} \\
\hline \multirow{5}{*}{ SCFAs } & & $\begin{array}{l}\text { Reduced pro-inflammatory response } \\
\text { in combination with polyphenols (i.e., } \\
\text { epigallocatechin gallate, resveratrol) }\end{array}$ & & [110-112] \\
\hline & & $\begin{array}{l}\text { GPR41/GPR43-mediated signaling } \\
\text { pathways }\end{array}$ & & [103] \\
\hline & & Inhibition of NF- $\mathrm{KB}$ activation & & [104] \\
\hline & & $\begin{array}{l}\text { Anti-inflammatory IL-10 release via } \\
\text { HDACs inhibition }\end{array}$ & & [105-107] \\
\hline & $\begin{array}{l}\text { GPCRs-mediated inflammatory } \\
\text { responses }\end{array}$ & & & {$[108,109]$} \\
\hline \multirow[t]{3}{*}{ MUFAs } & & $\begin{array}{l}\text { Downregulation of IL-1 } \beta \text { and IL-18 } \\
\text { expression via NLRP3 inflammasome } \\
\text { inhibition }\end{array}$ & & [7] \\
\hline & & $\begin{array}{l}\text { AMPK-mediated anti-inflammatory } \\
\text { response }\end{array}$ & & [95] \\
\hline & & $\begin{array}{l}\text { Do not activate TLR2/TLR4 signaling } \\
\text { pathways }\end{array}$ & & [96] \\
\hline \multirow[t]{2}{*}{$\omega-6$ PUFAs } & $\begin{array}{l}\text { ARA-derived eicosanoids, such } \\
\text { as HPETE, PG, TX, LT, and } \\
\text { lipoxins, induce inflammatory } \\
\text { response via GPCRs }\end{array}$ & & & [81] \\
\hline & & & $\begin{array}{l}\text { Promote obesity, } \\
\text { T2DM, arthritis }\end{array}$ & [91-93] \\
\hline
\end{tabular}


Table 1. Cont.

\begin{tabular}{|c|c|c|c|c|}
\hline Fatty Acids & Pro-Inflammatory Effect & Anti-Inflammatory Effect & Other Effects & References \\
\hline \multirow[t]{2}{*}{$\omega-3$ UFAs } & & $\begin{array}{l}\text { EPA/DHA-derived eicosanoids, such } \\
\text { as resolvins, protectins, and maresins, } \\
\text { induce a milder inflammatory } \\
\text { response and accelerate resolution of } \\
\text { inflammation } \\
\text { NF- } k B \text { signaling suppression via } \\
\text { PPAR- } \gamma \text { activation, impairment of } \\
\text { TLRs activation, and GPR40 and } \\
\text { GPR120-mediated anti-inflammatory } \\
\text { cascade } \\
\text { NLRP3 inflammasome inhibition }\end{array}$ & & $\begin{array}{l}{[86-90]} \\
{[102]}\end{array}$ \\
\hline & & & $\begin{array}{l}\text { Contrast obesity, } \\
\text { type } 2 \text { diabetes, } \\
\text { arthritis }\end{array}$ & [91-93] \\
\hline
\end{tabular}

\section{Nutrigenomics of Fats: Evidence from Animal Studies}

Experimental studies in animal models, conducted under ethical conditions, have provided the opportunity to evaluate molecular effects of various lipid mixtures or individual molecules, which could not be otherwise obtained from human studies. Indeed, animals fed with SFAs, MUFAs, or PUFAs showed differences in the activation of inflammatory pathways in healthy and unhealthy conditions, as well as contributed to elucidate the molecular mechanisms by which dietary lipids can modulate these metabolic pathways through gene expression changes.

For example, obese mice fed with a HFD (29.64\% SFA, 4.86\% PUFA) for 25 weeks developed a severe early psoriasiform skin inflammation, which was dependent on FFAs levels but independent of fat mass extension, blood glucose levels, and adipose tissuederived mediators. SFAs, which were increased by the HFD, were unraveled to sensitize myeloid cells, resulting in an amplified proinflammatory immune response to TLRs stimuli, which in turn augmented keratinocyte activation. On the other hand, dietary reduction of SFAs (0.73\% SFA, 3.73\% PUFA) dampened psoriasiform inflammation [114]. In another animal model, non-obese non-diabetic mice gavaged for one day with $\mathrm{PO}(2 \mathrm{~g} / \mathrm{kg}$ body weight), included in a low-fat diet (LFD) ( $13 \%$ of calories derived from fat, $17 \mathrm{~kJ} / \mathrm{g}$ ), showed an increase in hepatocellular lipids concentrations, lipid oxidation, and insulin resistance. Moreover, mouse transcriptomics revealed that PO differentially regulates pathways, including members of the TLRs and PPAR families, and NF- $\mathrm{KB}$ and TNF-related weak inducers of apoptosis [115]. Other experimental animal studies suggested that dietary SFAs ( $99.8 \%$ fat for 18 weeks) may directly promote the development of heart failure by inducing lipotoxicity [116]. SFAs, like lauric acid (C12:0) and myristic acid (C14:0), induced oxidative stress and myocardial fibrosis even in the absence of pressure overload if supplemented to a standard chow diet supplemented with $0.2 \%$ cholesterol and $10 \% \mathrm{CO}$ diet for eight weeks ad libitum in female C57BL/6 mice. This supplementation enhanced myocardial fibrosis, reduced capillary density, and increased myocardial cell apoptosis in postoperative pathological myocardial hypertrophy. Overall, it aggravated the pressure overload-induced cardiomyopathy [117]. High intake of SFAs, especially in presence of carbohydrates, has been shown to increase blood cholesterol, TG, and low-density lipoprotein cholesterol (LDL-C), which are associated to arterial lumen stenosis, atherosclerosis development, and increased risk of coronary heart disease. Furthermore, animal studies also correlated HFD (60\% pork lard for 16 weeks) to cognitive impairments [118].

Interestingly, the nutrigenomic effects of SFAs have been investigated and strongly differed from those of MUFAs. SFA-HFD containing 45\% kcal palmitic acid and MUFAHFD containing $45 \% \mathrm{kcal} \mathrm{OA}$ were fed to the eight to nine-week-old male C57BL $/ 6$ mice for 24 weeks. Despite an increased prevalence of obesity being observed in both HFD- 
contained groups, adipose IL-1 $\beta$ inflammation and insulin resistance were significantly lower in MUFA-HFD mice compared with the SFA-HFD group. A different regulation of IL$1 \beta$ production was observed; SFA-HFD induced pro-IL-1 $\beta$ and NLRP3-mediated activation through the down-regulation of AMPK. On the contrary, MUFA-HFD suppressed IL-1 $\beta$ activation via AMPK-mediated NLRP3 [7]. Compared with SFA-HFD, this bi-directional regulation of AMPK and IL-1 $\beta$ was mainly identified in the adipose tissue, where MUFAHFD retained adipose AMPK and weakened the activation of IL- $1 \beta$. In another study, LFD and SFA-HFD ( $45 \% \mathrm{kcal}$ PO) were used to feed seven to nine-week-old male C57BL/6J mice for 32 weeks consecutively. At the same time, another group of mice was fed with SFAHFD for 16 weeks and then switched to MUFA-HFD ( $45 \% \mathrm{kcal}$ sunflower oil) for another 16 weeks (SFA-to-MUFA-HFD). In SFA-HFD group, the expression of genes involved in $\beta$-cell differentiation, proliferation, and identity (such as Ins2, Nkx6.1, Ngn3, and Rfx6, as well as $P d x 1$ and $P a x 6$ ) was significantly reduced in pancreatic islet; this SFA-HFD-induced down-regulation was related to the impairment of cell functions. Interestingly, SFA-toMUFA-HFD reduced hyper-insulinemia, pancreatic inflammation, and the progression of $\beta$-cell function impairment induced by SFA-HFD, which may mediate its effects in an IL-1 $\beta$-AMPK-dependent manner [119]. This outcome highlights how the substitution of SFAs with MUFAs can restore impaired cellular responses. Indeed, other animal studies also showed that the detrimental effects of an unbalanced intake of dietary lipids can be reversed. In a study protocol, 12 week-old male C57BL/6 J mice were fed either a LFD or HFD (containing either 10 or $60 \%$ of the total caloric intake from fat, for 3 days, 1 week, or 2 weeks); one group of mice was fed the HFD for one week and then returned to the LFD for a further week. Results showed that after three days, one week, and two weeks, the HFD induced changes in the hippocampal proteins involved in metabolism, inflammation, cell stress, cell signaling, and cytoskeleton. However, the replacement of the HFD after one week by a LFD for a further week resulted in a partial recovery of the hippocampal proteome [120].

Concerning PUFAs, recent findings have shown that $\omega-3$ and derivatives $(0.31 \%$ or $1.25 \%$ of DHA for $4-5$ weeks) can reduce the stimulation of inflammatory factors and promote the regression of inflammation during cardiovascular processes [121]. Nine-weekold male C57BL $/ 6 \mathrm{ApoE}^{-/-}$mice were fed a HFD containing 20\% lard for four weeks, and then fed with both $1 \%$ dietary DHA incorporated into phospholipids (DHA-PL) and EPA incorporated into phospholipids (EPA-PL) for another eight weeks. The results showed that DHA-PL and EPA-PL could markedly reduce the atherosclerotic lesions in $\mathrm{ApoE}^{-/-}$mice. EPA-PL significantly reduced serum and liver lipid levels by mediating mRNA and protein levels of genes involved in hepatobiliary sterol metabolism, while the transcription of TNF$\alpha$, IL-6, and IL-1 $\beta$ was decreased by DHA-PL treatment [122]. The DHA-PL exerted mainly anti-inflammatory functions, while the EPA-PL was able to improve lipid metabolism in atherosclerosis. To study whether the anti-atherosclerotic effect of EPA-rich fish oil partly depends on the chemical group at $\omega-3$ position, the 18-19 week-old male $\mathrm{ApoE}^{-/-}$mice (C57BL/6J background) were used and clustered into three groups. In the model group, animals were fed with a HFD, while in the two study groups, animals were fed with a HFD containing 1\% EPA-PL or 1.1\% EPA incorporated into triglycerides (EPA-TG) (providing equal amounts of EPA) for 8 weeks. Compared with the control group, both EPA-PL and EPA-TG showed a reduction in the aortic atherosclerotic lesion area and inhibition of inflammatory markers in the aorta and circulation, with a better effect in presence of EPA-PL than EPA-TG. It should be noted that the serum and liver lipid levels of EPA-PL were lower than those of the model group, while EPA-TG only reduced the liver TG level. It has been proposed that EPA-PL has some initial advantages over EPA-TG in terms of bioavailability and therapeutic efficacy, which may be due to their structural differences at the $\omega-3$ site [123]. In addition, $\omega-3$ PUFAs can reduce blood pressure in rats, and the effect may depend on the membrane of the ion channels [124,125]. Due to positive effects on vascular function and blood pressure, but also due to their nutrigenomic properties, $\omega-3$ 
PUFAs (EPA $3.7 \mathrm{~g} / \mathrm{kg} /$ day and DHA $3 \mathrm{~g} / \mathrm{kg} /$ day for 20 weeks) are considered promising anti-atherosclerotic agents [126,127].

In addition, $\omega-3$ PUFAs can play an important role in central metabolism. Intracerebroventricular infusion of resolvin D1 (10 ng) and resolvin D2 (10 ng), bioactive lipid mediators generated from the $\omega-3$ PUFAs DHA and EPA, produced antidepressant effects in male BALB/c mice (8-12 weeks old) via the mammalian target of rapamycin complex 1 signaling pathway, at the medial prefrontal cortex and dentate gyrus, which are important brain regions for these antidepressant effects [128]. Wen et al., studied in an animal model of Alzheimer's disease (AD), obtained treating male Sprague Dawley rats with $\mathrm{A} \beta_{1-40}$, the protective effect of low $(150 \mathrm{mg} / \mathrm{kg}$ body weight $)$ and high $(300 \mathrm{mg} / \mathrm{kg}$ body weight) doses of EPA-PL for 27 days. The results showed that both low and high dose of EPA-PL improved cognitive performance in Morris Water Maze in AD rats [129]. Furthermore, treatment with EPA-PL increased the time of target phase and the numbers of crossing platform. Meanwhile, EPA-PL groups also significantly decreased the level of MDA, apoptosis, hyper-phosphorylated Tau, CD11b, glial fibrillary acidic protein (GFAP), IL-1 $\beta$, TNF- $\alpha$, and increased the level of SOD in the brain of $A \beta_{1-40}$-induced rats [129].

Finally, effects of $\omega-3$ PUFAs on DNA methylation in tumors have also been observed $[130,131]$. Colorectal cancer (CRC) rat model was developed using N-methyl phosphite nitrourea, and six-week-old rats were fed with $\omega-3$ PUFAs $(1 \mathrm{~g} / \mathrm{kg}$ body weight) for 12 weeks. The results showed that tumor incidence in $\omega-3$ treated rats was much lower than in CRC model rats, suggesting a significant protective role of $\omega-3$ PUFAs. Furthermore, 5 -methylcytosine content in $\omega-3$ PUFAs treated rats was higher than in CRC model rats, suggesting that $\omega-3$ PUFAs might regulate cytosine methylation. Therefore, it has been hypothesized that $\omega-3$ PUFAs could inhibit tumor growth through the regulation of DNA methylation [132]. Indeed, despite some contrasting findings [133,134], the involvement of epigenetic pathways in the mediation of the molecular effects of HF diets has been described. For example, methyl donor supplementation containing $5 \mathrm{~g} / \mathrm{kg}$ diet of betaine, $5.37 \mathrm{~g} / \mathrm{kg}$ of choline, $5.5 \mathrm{mg} / \mathrm{kg}$ of folic acid, and $0.5 \mathrm{mg} / \mathrm{kg}$ of vitamin B12 in HFD-fed for eight weeks ad libitum Wistar rats prevented the HFD-induced fat accumulation in the liver and modified mRNA hepatic profile, as well as the methylation of specific gene promoters [135]. Interestingly, it has been demonstrated that detrimental effects of HFD can be reversible, at the level of both the epigenotype and the phenotype [136].

In conclusion, animal studies highlight that dietary fatty acids not simply are a major energy source for the body, but also contribute to modulate various biological responses accordingly to their chemical features (Table 2).

Table 2. Impact of dietary fatty acids on gene mediated inflammatory responses/outcomes: studies in animal models.

\begin{tabular}{|c|c|c|c|c|}
\hline Fatty Acids & $\begin{array}{c}\text { Pro-Inflammatory } \\
\text { Effect }\end{array}$ & $\begin{array}{c}\text { Anti-Inflammatory } \\
\text { Effect }\end{array}$ & Other Effects & References \\
\hline $\begin{array}{l}\text { PO } \\
(2 \mathrm{~g} / \mathrm{kg} \text { body weight })\end{array}$ & & & $\begin{array}{l}\text { increase LOX and insulin } \\
\text { resistance }\end{array}$ & [115] \\
\hline $\begin{array}{l}\text { HFD } \\
(29.64 \% \text { SFAs, and } 4.86 \% \\
\text { PUFAs) }\end{array}$ & $\begin{array}{l}\text { IL-1 } \beta, \text { IL-6, TNF- } \alpha, \text { OP, } \\
\text { Cox2, SA8, SA9, } \\
\text { CXCL1, CCL3 }\end{array}$ & & & [114] \\
\hline $\begin{array}{l}\text { SFAs } \\
(99.8 \% \text { fat })\end{array}$ & & & $\begin{array}{l}\text { induce cardiac hypertrophy, } \\
\text { left ventricular systolic, and } \\
\text { diastolic dysfunction, and } \\
\text { autophagy }\end{array}$ & [116] \\
\hline $\begin{array}{l}\text { SFAs }(0.2 \% \text { cholesterol } \\
\text { and } 10 \% \mathrm{CO})\end{array}$ & & & $\begin{array}{l}\text { reduce oxidative stress and } \\
\text { myocardial fibrosis }\end{array}$ & [117] \\
\hline HFD $(60 \%$ pork lard $)$ & IL-6, TNF- $\alpha$, MCP-1 & & disrupt cognition & [118] \\
\hline
\end{tabular}


Table 2. Cont.

\begin{tabular}{|c|c|c|c|c|}
\hline Fatty Acids & $\begin{array}{l}\text { Pro-Inflammatory } \\
\text { Effect }\end{array}$ & $\begin{array}{l}\text { Anti-Inflammatory } \\
\text { Effect }\end{array}$ & Other Effects & References \\
\hline HFD $(60 \%$ kcal $)$ & & & $\begin{array}{l}\text { metabolism, cellular stress } \\
\text { responses, cyto-skeletal } \\
\text { organization, cell signaling, } \\
\text { and the immune system }\end{array}$ & [120] \\
\hline $\begin{array}{l}\text { MUFA-HFD (45\% kcal } \\
(\mathrm{OA}))\end{array}$ & & NLRP3, IL-1 $\beta$, IL-18 & improve insulin sensitivity & [7] \\
\hline $\begin{array}{l}\text { MUFA-HFD } \\
\text { (45\% kcal sunflower oil) }\end{array}$ & & IL-1 $\beta$, IL-6 & attenuate hyperinsulinemia & [119] \\
\hline $\begin{array}{l}\text { PUFAs } \\
\text { ( } 0.31 \% \text { or } 1.25 \% \text { of DHA) }\end{array}$ & & & $\begin{array}{l}\text { reduce heart rate and } \\
\text { arrhythmia vulnerability }\end{array}$ & [121] \\
\hline $\begin{array}{l}\text { DHA-PL, EPA-PL } \\
\text { (1\% dietary DHA or EPA } \\
\text { incorporated into } \\
\text { phospholipids) }\end{array}$ & & $\begin{array}{l}\text { TNF- } \alpha, \text { IL-6, IL-1 } \beta, \\
\text { CD68 }\end{array}$ & reduce atherosclerotic lesions & [122] \\
\hline $\begin{array}{l}\text { EPA-PL } \\
(1 \% \text { EPA-PL) }\end{array}$ & & $\begin{array}{l}\text { CRP, TNF- } \alpha, \text { IL-6, } \\
\text { MCP-1 }\end{array}$ & regulate cholesterolmetabolism & [123] \\
\hline $\begin{array}{l}\text { resolvin D1 (10 ng) and } \\
\text { D2 (10 ng) }\end{array}$ & & & $\begin{array}{l}\text { antidepressant, activation of } \\
\text { mTORC1 signaling }\end{array}$ & [128] \\
\hline $\begin{array}{l}\text { EPA-PL } \\
\text { (150 or } 300 \mathrm{mg} / \mathrm{kg} \text { body } \\
\text { weight) }\end{array}$ & & $\begin{array}{l}\text { CD11b, GFAP, IL-1 } \beta \text {, } \\
\text { TNF- } \alpha\end{array}$ & $\begin{array}{l}\text { alleviate oxidative stress, and } \\
\text { hyper-phosphorylated tau }\end{array}$ & [129] \\
\hline $\begin{array}{l}\omega-3 \text { PUFAs } \\
(12 \% \text { fish iol })\end{array}$ & & & mtDNA methylation & [130] \\
\hline $\begin{array}{l}\omega-3 \text { PUFAs } \\
(0.5 \% \text { EPA and DHA) }\end{array}$ & & & DNA methylation & [131] \\
\hline $\begin{array}{l}\omega-3 \text { PUFAs } \\
(1 \mathrm{~g} / \mathrm{kg} \text { body weight })\end{array}$ & & & DNA methylation & [132] \\
\hline
\end{tabular}

\section{Nutrigenomics of Fats: Evidence from Human Studies}

Growing evidence has shown that FAs may exert many of their biological effects by regulating the activity of several transcription factors [137]. For example, $\omega-3$ FAs can influence the expression of several genes involved in lipid and carbohydrate metabolism, thermogenesis, and inflammatory processes by inducing sterol regulatory element binding proteins (SREBPs), PPARs, carbohydrate response element binding protein (ChREBP), and NF- $\mathrm{KB}[138]$.

As aforementioned, $\omega-3$ PUFAs are natural PPARs ligands. In this context, a shortterm DHA-rich fish oil supplementation ( $2400 \mathrm{mg}$ /day for 8 weeks) increased PPAR $\gamma$ activity in peripheral blood mononuclear cells (PBMCs) of subjects with T2DM compared to placebo, improving lipid metabolism and energy homeostasis [139]. In agreement with such trial, the intake of $\omega-3$ FAs from flaxseed oil $(2 \times 1000 \mathrm{mg} /$ day, containing $400 \mathrm{mg}$ $\alpha$-linolenic acid, for 6 weeks) induced upregulation of PPAR $\gamma$ and low-density lipoprotein receptor $(L D L R)$ genes and downregulation of $I L-1$ and $T N F-\alpha$ in PBMCs of subjects with gestational diabetes compared to placebo. In addition, $\omega-3$ supplementation also improved glycemic and lipid profiles, inflammatory markers, and oxidative stress when compared to placebo [140]. Moreover, another study demonstrated that supplementation with $\omega-3$ PUFAs (2700 mg/day) enhanced nuclear factor erythroid 2-related factor 2 (NRF2) gene expression in PBMCs of subjects with T2DM [141]. NRF2 is a transcription factor that regulates the expression of antioxidant proteins that protect against oxidative damage triggered by injury and inflammation [142].

Regarding Parkinson disease, supplementation with $1000 \mathrm{mg} /$ day of $\omega-3$ FAs from flaxseed oil and $400 \mathrm{IU} /$ day of vitamin $\mathrm{E}$ for 12 weeks significantly improved gene expression of TNF- $\alpha, P P A R \gamma$ and LDLR, but did not affect IL-1 and IL-8 compared to placebo [143]. Additionally, supplementation with 50,000 IU of vitamin D every two weeks 
plus $2000 \mathrm{mg}$ / day of $\omega$-3 FAs from fish oil for 12 weeks also presented beneficial effects on gene expression of IL-1 and vascular endothelial growth factor (VEGF) among women with polycystic ovary syndrome [144].

Genes involved in lipid metabolism were differentially expressed in PBMCs depending on $\omega-3$ and $\omega-6$ plasmatic levels and on the ratio of SFAs to PUFAs in healthy subjects [145]. In subcutaneous adipose tissue of subjects with obesity, high medium-chain-SFAs diet led to upregulation of genes related to citric acid cycle and oxidative phosphorylation, and downregulation of genes related to complement system and inflammation [146]. Moreover, the replacement of SFAs with PUFAs induced upregulations of liver $\mathrm{X}$ receptoralpha $(L X R A)$ and LDLR, while the expression of several LXRA target genes and genes involved in inflammation was downregulated in PBMCs of healthy subjects with moderate hypercholesterolemia [147]. Taking all this information together, diet rich in $\omega-3$ may be beneficial for human health. However, further studies are necessary to elucidate the $\omega-3$ effects in the pathogenesis of several diseases [138].

Mediterranean diet (MedDiet) has been proven to be highly effective in the prevention of cardiovascular diseases and cancer and in decreasing overall mortality. In this context, MedDiet, especially if supplemented with extra virgin olive oil (EVOO), can exert health benefits through inducing changes in gene expression in pathways associated with cardiovascular risk [148]. Additionally, MedDiet enriched in MUFAs with EVOO can module the postprandial antioxidant profile, and the expression of proinflammatory and oxidative stress-related genes, including NF-kB p65, monocyte chemoattractant protein-1 (MCP-1), TNF- $\alpha$, NF- $k B$ inhibitory $\alpha(I k B \alpha), S O D 1$, upstream transcription factor 1 (USF1), and catalase $[149,150]$. The consumption of a functional VOO enriched with olive oil $(250 \mathrm{mg} / \mathrm{kg})$ and thyme phenolic compounds $(250 \mathrm{mg} / \mathrm{kg}$ ) upregulated the expression of key cholesterol efflux regulators (CYP27A1, CAV1, LXRB, RXRA) and nuclear receptor-related genes $(\mathrm{PPARb} / \gamma)[151]$.

Moreover, a study on 36 representative individuals selected within the PREvención con DIeta MEDiterránea (PREDIMED—Navarra) trial showed that nuts and EVOO were able to change the DNA methylation profile of several genes in peripheral blood leukocytes, with potentially beneficial effects for health (concerning genes related to intermediate metabolism, diabetes, inflammation, and signal transduction) [152]. This evidence contributes to explain the role of MedDiet and fat quality on health outcomes [153].

On the basis of gene-dietary fat interaction, several single nucleotide polymorphisms (SNPs) modulate the effects of certain dietary factors or food preferences, and the main results are shown in Table 3. Among these genes, the most studied ones are adiponectin, $\mathrm{C} 1 \mathrm{Q}$, and collagen domain containing (ADIPOQ), apolipoproteins, C-reactive protein $(C R P)$, fatty acid desaturase 1 (FADS1), fatty acid desaturase 2 (FADS2).

The $A D I P O Q$ gene encodes for the adiponectin protein, which exerts anti-inflammatory, antioxidant, and insulin sensitizer effects [154]. Several SNPs in ADIPOQ gene have been associated with serum adiponectin levels (Table 3), interacting with dietary FAs [155-157]. Additionally, the rs2241766 SNP interrelates with $\omega-3$ FAs changing serum adiponectin levels and other inflammatory biomarkers $[155,156]$.

On the other hand, two SNP located at APOE gene (rs7412 and rs429358) modify apolipoprotein E mRNA codon 112 and 158, where cysteine is replaced by arginine in both positions, and hence forms three possible isoforms of the protein according to the resultant salt-bridges: $\varepsilon 2$, $\varepsilon 3$, and $\varepsilon 4$ [158-161]. In this way, after eight weeks of a high-SFAs diet [162], increased CRP levels was observed in APOE $\varepsilon 4$ carriers (high risk allele). In the same way, in the Food4Me study, the $\varepsilon 4$ allele was associated with higher total cholesterol compared to non-risk genotypes [161]. Additionally, a 16-week dietary intervention with a replacement of 9.5\% energy of MUFAs or $\omega-6$ FAs, reduced plasmatic CRP levels in APOE $\varepsilon 4$ carriers, while $A P O E \varepsilon 3 / \varepsilon 3$ carriers showed an opposite increment in CRP concentration [163].

Reports indicate that SNPs in CRP gene can change plasma CRP levels [164-166]. Additionally, higher intake of total PUFAs was associated with lower CRP levels, suggesting reduced chronic systemic inflammation [167]. Additionally, greater adherence to the 
MedDiet and particularly its fish component was associated with lower CRP blood levels, especially in those at highest genetic risk due to the CRP rs3093068 SNP [166]. Moreover, SNPs in CRP gene modulated the risk of inflammation, which depends on individual plasma fatty acid and lipid profile [168].

Recent data suggest that there is an association between fatty acid desaturase (FADS13) SNPs and lipid composition in human blood and tissues [169]. A systematic review identified that FADS SNPs may influence plasma and erythrocyte FA composition, as well as T2DM risk markers, such as HOMA-IR and fasting glucose [170]. In the same way, the presence of two common FADS haplotypes influences the ability to synthesize essential $\omega-3$ and $\omega-6$ LC-PUFAs (e.g., ARA and DHA). Additionally, the haplotype D was associated with increased FADS activity [171]. The FADS1 rs174537 SNP impacts the synthesis of ARA and the overall capacity of whole blood to synthesize 5-lipoxygenase products [172]. Additionally, the rs174537T allele was associated with decrease in DGLA, ARA levels [173], and diminished delta-5 desaturase enzyme activity, and FADS1 gene expression [174]. Another common FADS1 SNP, rs174550, modifies metabolic responses to an LA-enriched $\operatorname{diet}(6 \%$ of total energy), influencing serum CRP and plasma fasting glucose levels and ARA proportion in men [175]. Considering that FADS1 and FADS2 code for key enzymes for the conversion of the $\omega-6$ and $\omega-3$ C18 FA to their respective $C 20$ and C22 products, SNPs in these genes could alter the viability of these products.

In the context of nutrigenetics, it is difficult to predict the impact that a variant may have on the gene-diet interaction, especially because the genetic variation differs across populations. For example, the frequency of FADS polymorphisms changes according to the population, which could alter the efficiency of $\omega-6$ and $\omega-3$ in the diet [176]. The results of the aforementioned studies suggest that the interaction between genetic factors, especially SNPs, and dietary components can alter the response to nutritional interventions and, consequently, susceptibility to several diseases.

Although we already know the gene-diet interaction, current strategies are based on nutritional recommendations for populations in general, not considering the influence of genetic factors on dietary components, such as lipids. Among the lipids-gene interaction mentioned in this section, most studies have demonstrated a crosstalk between $\omega-3$ and genetic polymorphisms, as evidenced in Table 3 . In this sense, a genetic risk score constructed from genes identified by genome association studies, partially explained the variation in changes in TG in response to supplementation with $\omega-3$ FAs [5 g/day of fish oil (1.9-2.2 g EPA and $1.1 \mathrm{~g}$ DHA daily)] [177]. This finding, added to the others previously mentioned in this section, reinforces the importance of knowing the individual's genetics background for the prescription of nutritional supplementation.

In this context, precision nutrition is an important part of personalized medicine and an emerging approach to disease prevention and treatment that takes genetic information in consideration, as well as age, sex, pathophysiological status, and environmental issues, including dietary patterns $[178,179]$. Nutritional prescriptions should consider the diversity in the genetic background between individuals and ethnic groups, as it affects nutritional needs, metabolism, and the response to nutritional and dietary interventions. Thus, knowledge about nutrigenetics and nutrigenomics can allow health professionals to decide on the most appropriate treatment to achieve precision nutrition, as well as permitting the design of innovative strategies for the prevention, control, and treatment of several diseases $[176,179]$.

Although nutrigenomics is extremely important for the implementation of precision nutrition, these studies still have limitations. First, several studies are still scarce and heterogeneous, which makes it difficult to compare apparently similar studies that analyze the same genetic variants and dietary components. Second, genomic data requires a comprehensive analysis of bioinformatics, which makes it difficult to understand the results. Third, it is necessary to integrate the results of several omics studies in order to have more robust findings. 
Table 3. Gene-dietary fat interactions mediating inflammation and lipid metabolism. $\uparrow$ higher levels; $\downarrow$ lower levels.

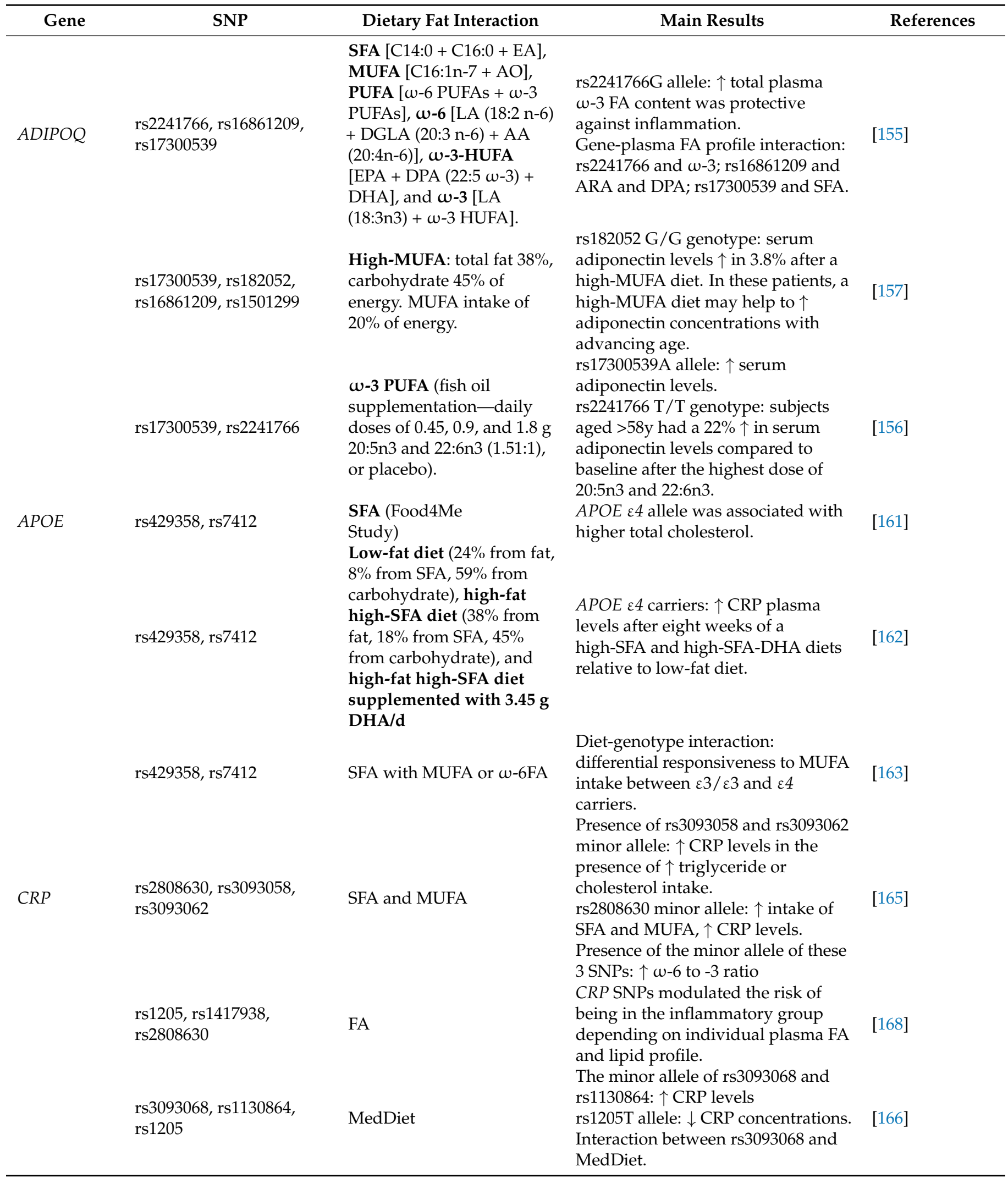


Table 3. Cont.

\begin{tabular}{|c|c|c|c|c|}
\hline Gene & SNP & Dietary Fat Interaction & Main Results & References \\
\hline $\begin{array}{l}\text { FADS } \\
\text { cluster }\end{array}$ & $\begin{array}{l}\text { FADS1: rs174537; FADS2: } \\
\text { rs174575, rs2727270; } \\
\text { FADS3: rs1000778 }\end{array}$ & $\omega-3$ and $\omega-6$ & $\begin{array}{l}\text { The presence of rs174537, rs174575, } \\
\text { and rs2727270 minor alleles: } \uparrow \text { LA } \\
\text { levels } \\
\text { rs174537T and rs2727270T: } \downarrow \text { DGLA } \\
\text { and ARA levels } \\
\text { rs1000778T allele: } \downarrow \text { ARA levels }\end{array}$ & [173] \\
\hline $\begin{array}{l}\text { FADS } \\
\text { haplotype }\end{array}$ & 28 closely linked SNPs & $\omega-3$ and $\omega-6$ & $\begin{array}{l}\text { Two common FADS haplotype differ } \\
\text { in their ability to generate } \\
\text { LC-PUFAs. }\end{array}$ & [171] \\
\hline \multirow[t]{3}{*}{ FADS1 } & rs174537 & ARA/LA & $\begin{array}{l}\text { rs174537 impacts the synthesis of } \\
\text { ARA and the overall capacity of } \\
\text { whole blood to synthesize } \\
\text { 5-lipoxygenase products. }\end{array}$ & [172] \\
\hline & rs174537 & PUFA & $\begin{array}{l}\text { rs174537T allele carriers: } \downarrow \text { in 20:4 } \\
\omega-6 \text { levels, } \downarrow \text { delta- } 5 \text { desaturase } \\
\text { enzyme activity, and } \downarrow \text { FADS1 gene } \\
\text { expression. }\end{array}$ & [174] \\
\hline & rs174550 & $\begin{array}{l}\text { Habitual diet with a } \\
\text { supplement of } 30,40 \text {, or } \\
50 \mathrm{~mL}(27-45 \mathrm{~g}) \text { sunflower } \\
\text { oil ( } 62 \% \text { of LA) daily } \\
\text { depending on BMI }\end{array}$ & $\begin{array}{l}\text { In men carrying the } \mathrm{T} / \mathrm{T} \text { genotype, } \\
\text { plasma eicosanoid concentrations } \\
\text { correlated with the ARA proportion } \\
\text { and with hsCRP. No correlations } \\
\text { were found for C/C genotype. }\end{array}$ & [175] \\
\hline
\end{tabular}

\section{Dietary Lipids Modulate Gut Microbiota Composition and Metabolites Production}

Microbial community in humans reaches the highest density and taxonomic diversity in the gastrointestinal tract, with an estimation of $10^{14}$ microorganisms and almost 2000 different species of bacteria in the colon [180]. Owing its multifaceted crosstalk with the host environment, the gut microbiota provides a range of beneficial properties to the host, with a significant impact on human health and disease [181]. Research about the gut microbiome has exponentially flourished in the last 20 years, providing also an insight into the dissection of the impact of different dietary patterns on the gut microbiota composition [182], including fats.

Despite most dietary FAs being absorbed in the small intestine, a certain percentage can reach the colon, directly modulating the gut microbiota composition and function [183]. Indeed, FAs have been found to have an antimicrobial activity [184] and also represent a substrate for bacteria [185], hence affecting gut metabolism and the host health.

Several animal studies investigated the impact of HFD enriched in SFAs (Table S1, Supplementary Materials): while bacterial diversity and richness did not show significant changes, in most of the studies SFAs intake induced a significant increase in the Firmicutes/Bacteroidetes ratio, which has been associated with obesity [186]. Negative effects of SFAs on the microbiota composition included the decrease in Bifidobacterium, a beneficial probiotics genus [187], the increase in Clostridium, a genus that also includes pathogenic strains [188], and the increase in Bilophila wadsworthia, a sulphide-producer bacteria, which has been associated with immune and metabolic impairments [189]. However, an increase in Ruminococcaceae, butyrate producing bacteria [190], has also been observed. Some studies also evidenced that a HFD leaded to gut-barrier alterations and consequent inflammation and gut-related disease [191-193].

Preliminary results from in vivo studies showed that a high intake of CC [194] or rapeseed oil [195], rich in medium-chain fatty acids (MCFAs), has a positive impact on gut microbiota in comparison to a diet rich in long-chain FAs, suggesting that the SFAs' chemical structure (e.g., in the length of FAs chains) may differentially affect the microbiota composition [195]. 
Since it is well known that trans-FAs, originated from hydrogenated vegetable oils, contribute to the development of chronic diseases [196], two recent studies investigated their impact also on animals' gut microbiota (Table S2, Supplementary Materials). They demonstrated that trans-FAs induce adverse effects, decreasing Bacteroidetes and increasing Firmicutes and Proteobacteria abundance $[197,198]$, the latter considered a signature of dysbiosis [199]; also, the families Ruminococcaceae, Lachnospiraceae, and Rikenellaceae were significantly reduced in mice that consumed hydrogenated soybean oil [197], supporting the hypothesis of a negative impact of trans-FAs on the gut microbiota composition and on health.

A few studies investigated the effect of MUFAs on the gut microbiota composition in animal models (Table S3, Supplementary Materials), suggesting an opposite effect than SFAs. In particular, MUFAs were associated with an increase in Bacteroidetes and a decrease in Firmicutes.

More data are available on PUFAs' effect (both $\omega-3$ and $\omega-6$, respectively described in Tables S4 and S5 Supplementary Materials). Overall, the regular consumption of $\omega-3$ has been associated with a condition of eubiosis, increasing probiotic bacteria such as Bifidobacterium, Lactobacillus, and Akkermansia [200-203] and SCFAs-producer families, such as Ruminococcaceae and Lachnospiraceae [200]. On the contrary, in vivo studies, where $\omega-6$ PUFAs were supplemented, showed a decrease in Bifidobacterium and Lactobacillus [192,204] and an increase in Clostridium [202,204], Firmicutes, and Proteobacteria [193].

Regarding studies on dietary lipids intake and gut microbiota in humans, a recent systematic review [205] analyzed and compared observational and interventional studies. Although the latter did not provide evidence of correlation between dietary fat intake and gut microbiota composition, observational studies evidenced interesting metabolic associations. Both types of studies showed a significant decrease in bacterial diversity and richness in participants consuming HFD enriched in SFAs. Differentially, a MUFAsenriched diet reduced the number of total bacteria and PUFAs-enriched diet did not induce any significant change in richness, diversity, and total number of bacteria [205]. Results from observational studies demonstrated positive correlations between (i) SFAs intake and bacterial genera such as Blautia and Clostridium, (ii) MUFAs intake and Blautia, (iii) PUFAs intake and Tenericutes, the latter associated with lower TG in plasma. The higher ratio Firmicutes/Bacteroidetes in subjects consuming SFAs is in accordance with results from studies in mice and correlated with obesity and inflammatory conditions. On the contrary, this effect was not found in participants consuming diets enriched in MUFAs or PUFAs. For an in depth description, see [205-207].

Although most studies have been conducted in animals and results are still not consistent, interesting findings are revealing, suggesting that HFD rich in SFAs exerts negative effects on the gut microbiota with consequences on human metabolism and health [208]; a diet rich in PUFAs may have a positive effect on microbial communities in human gut, supporting the beneficial role of these essential and anti-inflammatory dietary components on human health. On the contrary, effects of a diet rich in MUFAs on the gut microbiome composition are still inconclusive. Further studies might support the promising, but still complex, design of personalized diets able to modulate the microbiota composition also through the effect of specific FAs.

\section{Conclusions}

Plant- and animal-derived food differ in dietary lipid content and quality associated chemical characteristics, as well as for the presence of additional bioactive compounds and/or nutrients that contribute to the final effect on gene expression regulation (i.e., the nutrigenomic effect) (Figure 3). The chemical structure of lipids influences also their oxidative stability contributing to produce secondary metabolites with various impact on molecular responses. Research on animal models highlights how the type of FAs, their amount, and the time of exposure to a fat-rich diet can modulate cellular responses mediated by regulating gene expression, and significantly contributing to describe the 
nutrigenomic role of dietary lipids. However, going toward human studies, the picture becomes more complex, also because of the contribution of the individual genetic variability and the gut microbiota diversity. According to the gene-dietary fat interaction, SNPs contribute to produce multifaceted molecular responses, that may differ from outcomes obtained in vitro and/or in preclinical studies. Results from animal and human studies on gut microbiota composition partially contribute to characterize the response associated to dietary fat intake.

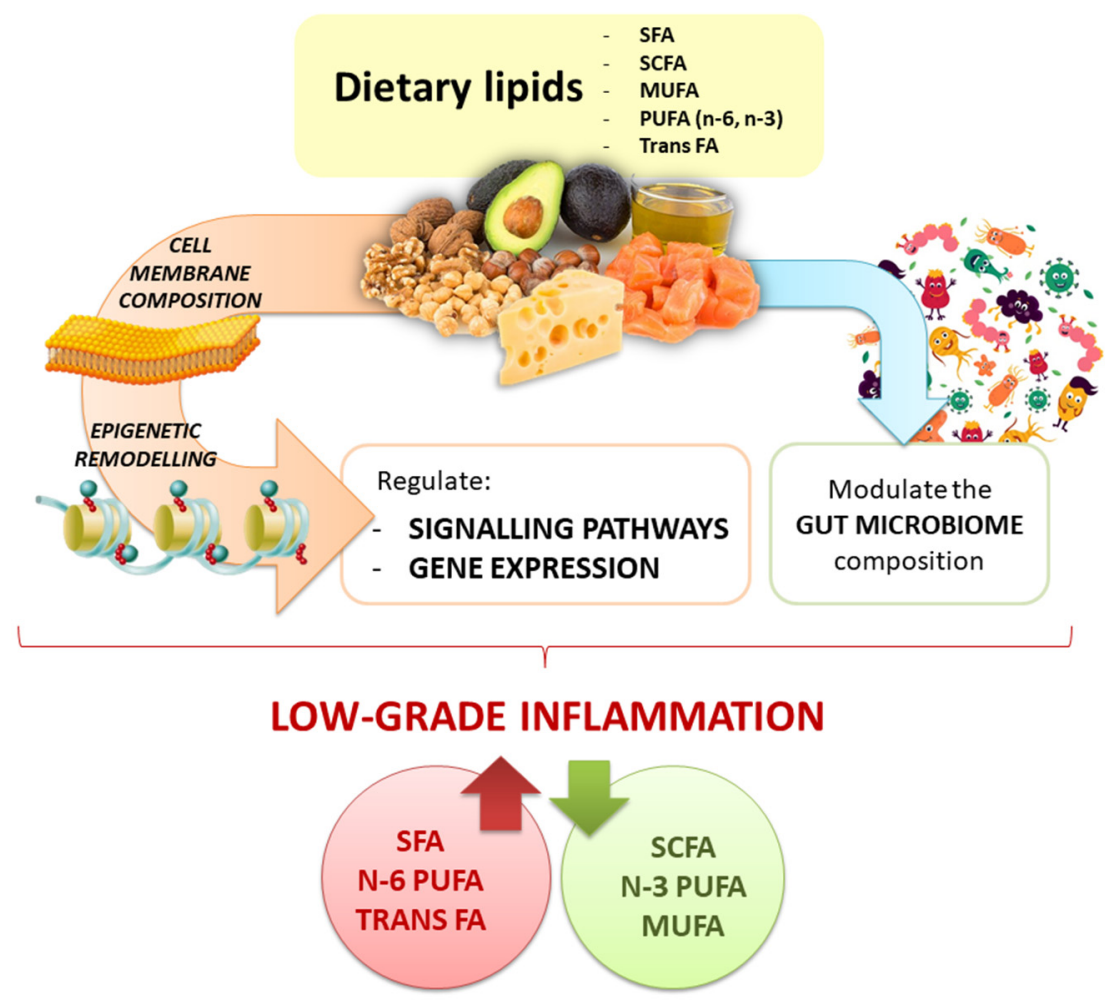

Figure 3. Graphical overview of the nutrigenomic impact of dietary lipids.

A major strength of the research production in this area relies on the specific contribution to describing the complex impact of dietary lipids on gene expression regulation. However, a major weakness in the characterization of this multifaceted picture still exists, especially in humans. This is at least partially due to the wide extent of the human genetic variability, which generates a plethora of different phenotypes, with heterogeneous responses to dietary factors, including lipids. The incorporation of nutrigenetic data into human studies might help to reduce this confounding factor. Genomics might be used for Mendelian randomization studies aimed to demonstrate causal effects of lipids on human health and diseases, reducing confounding and reverse causation [209]. Finally, a better understanding of the role of the microbiome and of metabolites that it produces (still only partially characterized because of the complexity of the system and the large inter-individual variations) might help to elucidate how it modulates the effect of dietary lipids in each individual.

In conclusion, to properly define the exact individual response to dietary lipids, the research on the nutrigenomics of dietary lipids urgently needs the confluence of omics domains (i.e., nutrigenomics, nutri-epigenetics, nutrigenetics, metabolomics, especially lipidomics, etc.) [210], which will strongly improve the possibility to translate this knowledge into clinical practice.

Supplementary Materials: The following are available online at https:/ / www.mdpi.com/article/ 10.3390/antiox10070994/s1, Table S1: The impact of HFD rich in saturated fats on gut microbiota 
composition in animals, Table S2: The impact of TFA (trans fatty acids) on gut microbiota composition in animals, Table S3: The impact of MUFA (monounsaturated fatty acids) on gut microbiota composition in animals, Table S4: The impact of PUFA-n-3 (polyunsaturated fatty acids-omega3) on gut microbiota composition in animals, Table S5: The impact of PUFA-n-6 (polyunsaturated fatty acids-omega6) on gut microbiota composition in animals.

Author Contributions: Conceptualization, L.B., R.G. and J.A.M.; writing-original draft preparation, I.P., E.P., F.Z., T.S.A. and R.G.; writing-review and editing, L.B., R.G., J.A.M. and W.M.; supervision, L.B., R.G. and J.A.M. All authors have read and agreed to the published version of the manuscript.

Funding: This research received no external funding.

Conflicts of Interest: The authors declare no conflict of interest.

\section{Abbreviations}

\begin{tabular}{|c|c|}
\hline $\mathrm{AD}$ & Alzheimer's disease \\
\hline ADIPOQ & Adiponectin, C1Q and collagen domain containing \\
\hline ALA & $\alpha$-Linolenic acid \\
\hline AMPK & $5^{\prime} \mathrm{AMP}$-activated protein kinase \\
\hline ARA & Arachidonic acid \\
\hline $\mathrm{CO}$ & Coconut oil \\
\hline ChREBP & Carbohydrate response element binding protein \\
\hline COX & Cyclooxygenase \\
\hline CRC & Colorectal cancer \\
\hline CRP & C-reactive protein \\
\hline DHA & Docosahexaenoic acid \\
\hline DGLA & Dihomo gamma-linolenic acid \\
\hline EPA & Eicosapentaenoic acid \\
\hline EA & Estearic acid \\
\hline EVOO & Extra virgin olive oil \\
\hline FAs & Fatty acids \\
\hline FADS & Fatty acid desaturase \\
\hline FFAs & Free fatty acids \\
\hline GFAP & Glial fibrillary acidic protein \\
\hline GPCRs/GPRz & G protein-coupled receptors \\
\hline HDACs & Histone deacetylases \\
\hline HFD & High-fat diet \\
\hline HPETE & Hydroperoxyeicosatetraenoic acid \\
\hline HUFA & Highly unsaturated fatty acid \\
\hline $\mathrm{IFN} \gamma$ & Interferon $\gamma$ \\
\hline IL & Interleukine \\
\hline IRF3 & Interferon regulatory factor 3 \\
\hline LA & Linoleic acid \\
\hline LDLR & Low density lipoprotein receptor \\
\hline LFD & Low-fat diet \\
\hline LOX & Lipoxygenase \\
\hline LTs & Leukotrienes \\
\hline LXRA & Liver $X$ receptor-alpha \\
\hline MAPK & Mitogen-activated protein kinase \\
\hline MCP-1 & Monocyte chemoattractant protein-1 \\
\hline MCFAs & Medium chain fatty acids \\
\hline MedDiet & Mediterranean diet \\
\hline MUFAs & Monounsaturated fatty acids \\
\hline MyD88 & Myeloid differentiation primary response 88 \\
\hline NADPH & Nicotinamide adenine dinucleotide phosphate \\
\hline NAFLD & Non-alcoholic fatty liver disease \\
\hline NF- $к B$ & Nuclear factor kappa B \\
\hline
\end{tabular}


NLRP3 Nucleotide-binding and oligomerization domain-like receptor, leucine-rich repeat and pyrin domain-containing 3 inflammasome

NRF2 Nuclear factor erythroid 2-related factor 2

OA Oleic acid

PBMCs Peripheral blood mononuclear cells

PGs Prostaglandins

PL Phospholipids

PO Palm oil

PPAR- $\gamma$ Peroxisome proliferator-activated receptor $\gamma$

PUFAs Polyunsaturated fatty acids

ROS Reactive oxygen species

SCFAs Short chain fatty acids

SCI Systemic chronic inflammation

SFAs Saturated fatty acids

SNPs Single nucleotide polymorphisms

SOD Superoxide dismutase

SREBPs Sterol regulatory element binding proteins

T2DM Type 2 diabetes mellitus

TG Triglycerides

TLRs Toll-like receptors

TNF $\alpha$ Tumor necrosis factor $\alpha$

TXs Thromboxanes

$\omega-3 \quad$ Omega-3 fatty acids

$\omega-6 \quad$ Omega-6 fatty acids

USF1 Upstream transcription factor 1

UCP2 Uncoupling protein 2

VEGF Vascular endothelial growth factor

\section{References}

1. Springmann, M.; Wiebe, K.; Mason-D'Croz, D.; Sulser, T.B.; Rayner, M.; Scarborough, P. Health and nutritional aspects of sustainable diet strategies and their association with environmental impacts: A global modelling analysis with country-level detail. Lancet Planet. Health 2018, 2, e451-e461. [CrossRef]

2. Gabbianelli, R.; Damiani, E. Epigenetics and neurodegeneration: Role of early-life nutrition. J. Nutr. Biochem. 2018, 57, 1-13. [CrossRef]

3. Bordoni, L.; Gabbianelli, R. Primers on nutrigenetics and nutri(epi)genomics: Origins and development of precision nutrition. Biochimie 2019, 160, 156-171. [CrossRef]

4. Petracci, I.; Gabbianelli, R.; Bordoni, L. The Role of Nutri(epi)genomics in Achieving the Body's Full Potential in Physical Activity. Antioxidants 2020, 9, 498. [CrossRef]

5. Furman, D.; Campisi, J.; Verdin, E.; Carrera-Bastos, P.; Targ, S.; Franceschi, C.; Ferrucci, L.; Gilroy, D.W.; Fasano, A.; Miller, G.W.; et al. Chronic inflammation in the etiology of disease across the life span. Nat. Med. 2019, 25, 1822-1832. [CrossRef] [PubMed]

6. Barabási, A.-L.; Menichetti, G.; Loscalzo, J. The unmapped chemical complexity of our diet. Nat. Food 2020, 1, 33-37. [CrossRef]

7. Finucane, O.M.; Lyons, C.L.; Murphy, A.M.; Reynolds, C.M.; Klinger, R.; Healy, N.P.; Cooke, A.A.; Coll, R.C.; McAllan, L.; Nilaweera, K.N.; et al. Monounsaturated fatty acid-enriched high-fat diets impede adipose NLRP3 inflammasome-mediated IL-1 $\beta$ secretion and insulin resistance despite obesity. Diabetes 2015, 64, 2116-2128. [CrossRef]

8. Nestel, P.J. Dietary Fat and Blood Pressure. Curr. Hypertens. Rep. 2019, 21, 17. [CrossRef] [PubMed]

9. Paszczyk, B.; Polak-Śliwińska, M.; Łuczyńska, J. Fatty Acids Profile, Trans Isomers, and Lipid Quality Indices in Smoked and Unsmoked Cheeses and Cheese-Like Products. Int. J. Environ. Res. Public Health 2019, 17, 71. [CrossRef]

10. Al-Khalaifah, H. Modulatory Effect of Dietary Polyunsaturated Fatty Acids on Immunity, Represented by Phagocytic Activity. Front. Vet. Sci. 2020, 7, 569939. [CrossRef]

11. van der Gaag, E.J.; Wieffer, R.; van der Kraats, J. Advising Consumption of Green Vegetables, Beef, and Full-Fat Dairy Products Has No Adverse Effects on the Lipid Profiles in Children. Nutrients 2017, 9, 518. [CrossRef]

12. Ponnampalam, E.N.; Hopkins, D.L.; Jacobs, J.L. Increasing omega-3 levels in meat from ruminants under pasture-based systems. Rev. Sci. Tech. 2018, 37, 57-70. [CrossRef] [PubMed]

13. Kolarič, L.; Šimko, P. Determination of Cholesterol Content in Butter by HPLC: Up-to-Date Optimization, and In-House Validation Using Reference Materials. Foods 2020, 9, 1378. [CrossRef] [PubMed]

14. Wilczek, M.M.; Olszewski, R.; Krupienicz, A. Trans-Fatty Acids and Cardiovascular Disease: Urgent Need for Legislation. Cardiology 2017, 138, 254-258. [CrossRef]

15. Hu, F.B.; Willett, W.C. Optimal diets for prevention of coronary heart disease. JAMA 2002, 288, 2569-2578. [CrossRef] [PubMed]

16. Ginter, E.; Simko, V. New data on harmful effects of trans-fatty acids. Bratisl. Lek. Listy 2016, 117, 251-253. [CrossRef] 
17. Zhou, Y.; Zhao, W.; Lai, Y.; Zhang, B.; Zhang, D. Edible Plant Oil: Global Status, Health Issues, and Perspectives. Front. Plant Sci. 2020, 11, 1315. [CrossRef] [PubMed]

18. Chen, X.; Li, L.; Liu, X.; Luo, R.; Liao, G.; Li, L.; Liu, J.; Cheng, J.; Lu, Y.; Chen, Y. Oleic acid protects saturated fatty acid mediated lipotoxicity in hepatocytes and rat of non-alcoholic steatohepatitis. Life Sci. 2018, 203, 291-304. [CrossRef]

19. Zeng, X.; Zhu, M.; Liu, X.; Chen, X.; Yuan, Y.; Li, L.; Liu, J.; Lu, Y.; Cheng, J.; Chen, Y. Oleic acid ameliorates palmitic acid induced hepatocellular lipotoxicity by inhibition of ER stress and pyroptosis. Nutr. Metab. 2020, 17, 11. [CrossRef]

20. Storniolo, C.E.; Casillas, R.; Bulló, M.; Castañer, O.; Ros, E.; Sáez, G.T.; Toledo, E.; Estruch, R.; Ruiz-Gutiérrez, V.; Fitó, M.; et al. A Mediterranean diet supplemented with extra virgin olive oil or nuts improves endothelial markers involved in blood pressure control in hypertensive women. Eur. J. Nutr. 2017, 56, 89-97. [CrossRef]

21. Urpi-Sarda, M.; Casas, R.; Chiva-Blanch, G.; Romero-Mamani, E.S.; Valderas-Martínez, P.; Arranz, S.; Andres-Lacueva, C.; Llorach, R.; Medina-Remón, A.; Lamuela-Raventos, R.M.; et al. Virgin olive oil and nuts as key foods of the Mediterranean diet effects on inflammatory biomakers related to atherosclerosis. Pharmacol. Res. 2012, 65, 577-583. [CrossRef]

22. Pacetti, D.; Boarelli, M.C.; Giovannetti, R.; Ferraro, S.; Conti, P.; Alfei, B.; Caprioli, G.; Ricciutelli, M.; Sagratini, G.; Fedeli, D.; et al. Chemical and Sensory Profiling of Monovarietal Extra Virgin Olive Oils from the Italian Marche Region. Antioxidants 2020, 9, 330. [CrossRef] [PubMed]

23. Bordoni, L.; Fedeli, D.; Fiorini, D.; Gabbianelli, R. Extra Virgin Olive Oil and Nigella sativa Oil Produced in Central Italy: A Comparison of the Nutrigenomic Effects of Two Mediterranean Oils in a Low-Grade Inflammation Model. Antioxidants 2019, 9 , 20. [CrossRef] [PubMed]

24. Nasuti, C.; Fedeli, D.; Bordoni, L.; Piangerelli, M.; Servili, M.; Selvaggini, R.; Gabbianelli, R. Anti-Inflammatory, Anti-Arthritic and Anti-Nociceptive Activities of Nigella sativa Oil in a Rat Model of Arthritis. Antioxidants 2019, 8, 342. [CrossRef] [PubMed]

25. Bordoni, L.; Fedeli, D.; Nasuti, C.; Maggi, F.; Papa, F.; Wabitsch, M.; De Caterina, R.; Gabbianelli, R. Antioxidant and AntiInflammatory Properties of Nigella sativa Oil in Human Pre-Adipocytes. Antioxidants 2019, 8, 51. [CrossRef] [PubMed]

26. Smith, E.; Beamer, S.K.; Matak, K.E.; Jaczynski, J. Storage stability of egg sticks fortified with omega-3 fatty acids. J. Sci. Food Agric. 2018, 98, 3452-3461. [CrossRef]

27. Stupin, A.; Rasic, L.; Matic, A.; Stupin, M.; Kralik, Z.; Kralik, G.; Grcevic, M.; Drenjancevic, I. Omega-3 polyunsaturated fatty acids-enriched hen eggs consumption enhances microvascular reactivity in young healthy individuals. Appl. Physiol. Nutr. Metab. = Physiol. Appl. Nutr. Metab. 2018, 43, 988-995. [CrossRef] [PubMed]

28. Veena, N.; Surendra Nath, B.; Srinivas, B.; Balasubramanyam, B. V Quality attributes of dahi prepared from milk fortified with omega-3 fatty acids, phytosterols and polydetxrose. J. Food Sci. Technol. 2017, 54, 1765-1775. [CrossRef]

29. Stanton, A.V.; James, K.; Brennan, M.M.; O’Donovan, F.; Buskandar, F.; Shortall, K.; El-Sayed, T.; Kennedy, J.; Hayes, H.; Fahey, A.G.; et al. Omega-3 index and blood pressure responses to eating foods naturally enriched with omega-3 polyunsaturated fatty acids: A randomized controlled trial. Sci. Rep. 2020, 10, 15444. [CrossRef]

30. Nguyen, Q.V.; Malau-Aduli, B.S.; Cavalieri, J.; Malau-Aduli, A.E.O.; Nichols, P.D. Enhancing Omega-3 Long-Chain Polyunsaturated Fatty Acid Content of Dairy-Derived Foods for Human Consumption. Nutrients 2019, 11, 743. [CrossRef]

31. Li, Y.; Yuan, F.; Wu, Y.; Zhang, Y.; Gao, B.; Yu, L. Triacylglycerols and Fatty Acid Compositions of Cucumber, Tomato, Pumpkin, and Carrot Seed Oils by Ultra-Performance Convergence Chromatography Combined with Quadrupole Time-of-Flight Mass Spectrometry. Foods 2020, 9, 970. [CrossRef]

32. Yun, J.-M.; Surh, J. Fatty Acid Composition as a Predictor for the Oxidation Stability of Korean Vegetable Oils with or without Induced Oxidative Stress. Prev. Nutr. Food Sci. 2012, 17, 158-165. [CrossRef]

33. Tena, N.; Aparicio, R.; García-González, D.L. Virgin olive oil stability study by mesh cell-FTIR spectroscopy. Talanta 2017, 167, 453-461. [CrossRef] [PubMed]

34. Javed, A.; Imran, M.; Ahmad, N.; Hussain, A.I. Fatty acids characterization and oxidative stability of spray dried designer egg powder. Lipids Health Dis. 2018, 17, 282. [CrossRef]

35. Imran, M.; Nadeem, M.; Manzoor, M.F.; Javed, A.; Ali, Z.; Akhtar, M.N.; Ali, M.; Hussain, Y. Fatty acids characterization, oxidative perspectives and consumer acceptability of oil extracted from pre-treated chia (Salvia hispanica L.) seeds. Lipids Health Dis. 2016, 15, 162. [CrossRef]

36. Mazzocchi, A.; Leone, L.; Agostoni, C.; Pali-Schöll, I. The Secrets of the Mediterranean Diet. Does [Only] Olive Oil Matter? Nutrients 2019, 11, 2941. [CrossRef]

37. Kim, H.; Caulfield, L.E.; Garcia-Larsen, V.; Steffen, L.M.; Coresh, J.; Rebholz, C.M. Plant-Based Diets Are Associated With a Lower Risk of Incident Cardiovascular Disease, Cardiovascular Disease Mortality, and All-Cause Mortality in a General Population of Middle-Aged Adults. J. Am. Heart Assoc. 2019, 8, e012865. [CrossRef]

38. Dima, C.; Assadpour, E.; Dima, S.; Jafari, S.M. Bioavailability and bioaccessibility of food bioactive compounds; overview and assessment by in vitro methods. Compr. Rev. Food Sci. Food Saf. 2020, 19, 2862-2884. [CrossRef]

39. Martínez-Ramírez, H.R.; Kramer, J.K.G.; de Lange, C.F.M. Ileal flows and apparent ileal digestibility of fatty acids in growing gilts fed flaxseed containing diets. J. Anim. Sci. 2013, 91, 2729-2739. [CrossRef]

40. Just, A.; Andersen, J.O.; Jørgensen, H. The influence of diet composition on the apparent digestibility of crude fat and fatty acids at the terminal ileum and overall in pigs. Zeitschrift Tierphysiologie Tierernährung Futtermittelkd. 1980, 44, 82-92. [CrossRef]

41. Plourde, M.; Cunnane, S.C. Extremely limited synthesis of long chain polyunsaturates in adults: Implications for their dietary essentiality and use as supplements. Appl. Physiol. Nutr. Metab. = Physiol. Appl. Nutr. Metab. 2007, 32, 619-634. [CrossRef] 
42. Goyens, P.L.L.; Spilker, M.E.; Zock, P.L.; Katan, M.B.; Mensink, R.P. Conversion of alpha-linolenic acid in humans is influenced by the absolute amounts of alpha-linolenic acid and linoleic acid in the diet and not by their ratio. Am. J. Clin. Nutr. 2006, 84, 44-53. [CrossRef]

43. Gerster, H. Can adults adequately convert alpha-linolenic acid (18:3n-3) to eicosapentaenoic acid (20:5n-3) and docosahexaenoic acid (22:6n-3)? Int. J. Vitam. Nutr. Res. Int. Zeitschrift fur Vitamin- und Ernahrungsforschung. J. Int. Vitaminol. Nutr. 1998, 68, 159-173.

44. Schuchardt, J.P.; Hahn, A. Bioavailability of long-chain omega-3 fatty acids. Prostaglandins. Leukot. Essent. Fatty Acids 2013, 89, 1-8. [CrossRef]

45. Lawson, L.D.; Hughes, B.G. Absorption of eicosapentaenoic acid and docosahexaenoic acid from fish oil triacylglycerols or fish oil ethyl esters co-ingested with a high-fat meal. Biochem. Biophys. Res. Commun. 1988, 156, 960-963. [CrossRef]

46. Davidson, M.H.; Johnson, J.; Rooney, M.W.; Kyle, M.L.; Kling, D.F. A novel omega-3 free fatty acid formulation has dramatically improved bioavailability during a low-fat diet compared with omega-3-acid ethyl esters: The ECLIPSE (Epanova(®) compared to Lovaza $\left({ }^{\circledR}\right)$ in a pharmacokinetic single-dose evaluation) study. J. Clin. Lipidol. 2012, 6, 573-584. [CrossRef]

47. Kling, D.F.; Johnson, J.; Rooney, M.; Davidson, M. Omega-3 Free Fatty Acids Demonstrate More Than 4-Fold Greater Bioavailability for EPA and DHA Compared with Omega-3-acid Ethyl Esters in Conjunction with a Low-Fat Diet: The ECLIPSE Study ${ }^{\dagger}$. J. Clin. Lipidol. 2011, 5, 231. [CrossRef]

48. Offman, E.; Marenco, T.; Ferber, S.; Johnson, J.; Kling, D.; Curcio, D.; Davidson, M. Steady-state bioavailability of prescription omega-3 on a low-fat diet is significantly improved with a free fatty acid formulation compared with an ethyl ester formulation: The ECLIPSE II study. Vasc. Health Risk Manag. 2013, 9, 563-573. [CrossRef]

49. Shen, Z.; Apriani, C.; Weerakkody, R.; Sanguansri, L.; Augustin, M.A. Food matrix effects on in vitro digestion of microencapsulated tuna oil powder. J. Agric. Food Chem. 2011, 59, 8442-8449. [CrossRef]

50. Pineda-Vadillo, C.; Nau, F.; Guérin-Dubiard, C.; Bourlieu, C.; Capozzi, F.; Bordoni, A.; Dupont, D. In Vivo Digestion of Egg Products Enriched with DHA: Effect of the Food Matrix on DHA Bioavailability. Foods 2020, 10, 6. [CrossRef]

51. Lamothe, S.; Rémillard, N.; Tremblay, J.; Britten, M. Influence of dairy matrices on nutrient release in a simulated gastrointestinal environment. Food Res. Int. 2017, 92, 138-146. [CrossRef]

52. Fardet, A.; Dupont, D.; Rioux, L.-E.; Turgeon, S.L. Influence of food structure on dairy protein, lipid and calcium bioavailability: A narrative review of evidence. Crit. Rev. Food Sci. Nutr. 2019, 59, 1987-2010. [CrossRef]

53. Lamothe, S.; Corbeil, M.-M.; Turgeon, S.L.; Britten, M. Influence of cheese matrix on lipid digestion in a simulated gastro-intestinal environment. Food Funct. 2012, 3, 724-731. [CrossRef]

54. Michalski, M.C.; Genot, C.; Gayet, C.; Lopez, C.; Fine, F.; Joffre, F.; Vendeuvre, J.L.; Bouvier, J.; Chardigny, J.M.; Raynal-Ljutovac, K. Multiscale structures of lipids in foods as parameters affecting fatty acid bioavailability and lipid metabolism. Prog. Lipid Res. 2013, 52, 354-373. [CrossRef]

55. Kerr, B.J.; Kellner, T.A.; Shurson, G.C. Characteristics of lipids and their feeding value in swine diets. J. Anim. Sci. Biotechnol. 2015, 6, 30. [CrossRef]

56. Huang, C.; Chiba, L.I.; Bergen, W.G. Bioavailability and metabolism of omega-3 polyunsaturated fatty acids in pigs and omega-3 polyunsaturated fatty acid-enriched pork: A review. Livest. Sci. 2021, 243, 104370. [CrossRef]

57. Neubronner, J.; Schuchardt, J.P.; Kressel, G.; Merkel, M.; von Schacky, C.; Hahn, A. Enhanced increase of omega-3 index in response to long-term n-3 fatty acid supplementation from triacylglycerides versus ethyl esters. Eur. J. Clin. Nutr. 2011, 65, 247-254. [CrossRef]

58. Ghasemifard, S.; Turchini, G.M.; Sinclair, A.J. Omega-3 long chain fatty acid "bioavailability": A review of evidence and methodological considerations. Prog. Lipid Res. 2014, 56, 92-108. [CrossRef]

59. Schuchardt, J.P.; Schneider, I.; Meyer, H.; Neubronner, J.; von Schacky, C.; Hahn, A. Incorporation of EPA and DHA into plasma phospholipids in response to different omega-3 fatty acid formulations-a comparative bioavailability study of fish oil vs. krill oil. Lipids Health Dis. 2011, 10, 145. [CrossRef] [PubMed]

60. Wakil, A.; Mir, M.; Mellor, D.D.; Mellor, S.F.; Atkin, S.L. The bioavailability of eicosapentaenoic acid from reconstituted triglyceride fish oil is higher than that obtained from the triglyceride and monoglyceride forms. Asia Pac. J. Clin. Nutr. 2010, $19,499-505$.

61. Mozaffarian, D.; Lemaitre, R.N.; King, I.B.; Song, X.; Huang, H.; Sacks, F.M.; Rimm, E.B.; Wang, M.; Siscovick, D.S. Plasma phospholipid long-chain $\omega-3$ fatty acids and total and cause-specific mortality in older adults: A cohort study. Ann. Intern. Med. 2013, 158, 515-525. [CrossRef]

62. Shahidi, F.; Ambigaipalan, P. Omega-3 Polyunsaturated Fatty Acids and Their Health Benefits. Annu. Rev. Food Sci. Technol. 2018, 9, 345-381. [CrossRef]

63. Laidlaw, M.; Cockerline, C.A.; Rowe, W.J. A randomized clinical trial to determine the efficacy of manufacturers' recommended doses of omega-3 fatty acids from different sources in facilitating cardiovascular disease risk reduction. Lipids Health Dis. 2014, 13, 99. [CrossRef] [PubMed]

64. Cook, C.M.; Hallaråker, H.; Sæbø, P.C.; Innis, S.M.; Kelley, K.M.; Sanoshy, K.D.; Berger, A.; Maki, K.C. Bioavailability of long chain omega-3 polyunsaturated fatty acids from phospholipid-rich herring roe oil in men and women with mildly elevated triacylglycerols. Prostaglandins. Leukot. Essent. Fatty Acids 2016, 111, 17-24. [CrossRef] 
65. Yamada, S.; Kamada, N.; Amiya, T.; Nakamoto, N.; Nakaoka, T.; Kimura, M.; Saito, Y.; Ejima, C.; Kanai, T.; Saito, H. Gut microbiotamediated generation of saturated fatty acids elicits inflammation in the liver in murine high-fat diet-induced steatohepatitis. BMC Gastroenterol. 2017, 17, 136. [CrossRef] [PubMed]

66. Hirabara, S.M.; Curi, R.; Maechler, P. Saturated fatty acid-induced insulin resistance is associated with mitochondrial dysfunction in skeletal muscle cells. J. Cell. Physiol. 2010, 222, 187-194. [CrossRef] [PubMed]

67. Csala, M. [Hyper-free fatty acidemia-Insulin resistance and $\beta$-cell death]. Orv. Hetil. 2016, 157, 733-739. [CrossRef]

68. Chaurasia, B.; Summers, S.A. Ceramides-Lipotoxic Inducers of Metabolic Disorders. Trends Endocrinol. Metab. 2015, 26, 538-550. [CrossRef] [PubMed]

69. Capurso, C.; Capurso, A. From excess adiposity to insulin resistance: The role of free fatty acids. Vascul. Pharmacol. 2012, 57, 91-97. [CrossRef]

70. Oh, Y.S.; Bae, G.D.; Baek, D.J.; Park, E.-Y.; Jun, H.-S. Fatty Acid-Induced Lipotoxicity in Pancreatic Beta-Cells During Development of Type 2 Diabetes. Front. Endocrinol. 2018, 9, 384. [CrossRef]

71. Nishi, H.; Higashihara, T.; Inagi, R. Lipotoxicity in Kidney, Heart, and Skeletal Muscle Dysfunction. Nutrients 2019, $11,1664$. [CrossRef]

72. Tovar, A.R.; Torres, N. The role of dietary protein on lipotoxicity. Biochim. Biophys. Acta 2010, 1801, 367-371. [CrossRef]

73. Inoue, N.; Nagao, K.; Sakata, K.; Yamano, N.; Gunawardena, P.E.R.; Han, S.-Y.; Matsui, T.; Nakamori, T.; Furuta, H.; Takamatsu, K.; et al. Screening of soy protein-derived hypotriglyceridemic di-peptides in vitro and in vivo. Lipids Health Dis. $2011,10,85$. [CrossRef]

74. Dixon, S.J.; Lemberg, K.M.; Lamprecht, M.R.; Skouta, R.; Zaitsev, E.M.; Gleason, C.E.; Patel, D.N.; Bauer, A.J.; Cantley, A.M.; Yang, W.S.; et al. Ferroptosis: An iron-dependent form of nonapoptotic cell death. Cell 2012, 149, 1060-1072. [CrossRef]

75. Yang, W.S.; Kim, K.J.; Gaschler, M.M.; Patel, M.; Shchepinov, M.S.; Stockwell, B.R. Peroxidation of polyunsaturated fatty acids by lipoxygenases drives ferroptosis. Proc. Natl. Acad. Sci. USA 2016, 113, E4966-E4975. [CrossRef]

76. Butterfield, D.A. Brain lipid peroxidation and alzheimer disease: Synergy between the Butterfield and Mattson laboratories. Ageing Res. Rev. 2020, 64, 101049. [CrossRef]

77. Peña-Bautista, C.; Baquero, M.; Vento, M.; Cháfer-Pericás, C. Free radicals in Alzheimer's disease: Lipid peroxidation biomarkers. Clin. Chim. Acta 2019, 491, 85-90. [CrossRef]

78. Nishiyama, K.; Fujimoto, Y.; Takeuchi, T.; Azuma, Y.-T. Aggressive Crosstalk Between Fatty Acids and Inflammation in Macrophages and Their Influence on Metabolic Homeostasis. Neurochem. Res. 2018, 43, 19-26. [CrossRef]

79. Fritsche, K.L. The science of fatty acids and inflammation. Adv. Nutr. 2015, 6, 293S-301S. [CrossRef]

80. Marion-Letellier, R.; Savoye, G.; Ghosh, S. Polyunsaturated fatty acids and inflammation. IUBMB Life 2015, 67, 659-667. [CrossRef]

81. Calder, P.C.; Ahluwalia, N.; Albers, R.; Bosco, N.; Bourdet-Sicard, R.; Haller, D.; Holgate, S.T.; Jönsson, L.S.; Latulippe, M.E.; Marcos, A.; et al. A consideration of biomarkers to be used for evaluation of inflammation in human nutritional studies. Br. J. Nutr. 2013, 109, S1-S34. [CrossRef]

82. Serhan, C.N.; Petasis, N.A. Resolvins and protectins in inflammation resolution. Chem. Rev. 2011, 111, 5922-5943. [CrossRef]

83. Calder, P.C. Marine omega-3 fatty acids and inflammatory processes: Effects, mechanisms and clinical relevance. Biochim. Biophys. Acta 2015, 1851, 469-484. [CrossRef]

84. Serhan, C.N.; Chiang, N. Resolution phase lipid mediators of inflammation: Agonists of resolution. Curr. Opin. Pharmacol. 2013, 13, 632-640. [CrossRef]

85. Bannenberg, G.; Serhan, C.N. Specialized pro-resolving lipid mediators in the inflammatory response: An update. Biochim. Biophys. Acta 2010, 1801, 1260-1273. [CrossRef] [PubMed]

86. Calder, P.C. Omega-3 fatty acids and inflammatory processes: From molecules to man. Biochem. Soc. Trans. 2017, 45, 1105-1115. [CrossRef] [PubMed]

87. Marion-Letellier, R.; Savoye, G.; Ghosh, S. Fatty acids, eicosanoids and PPAR gamma. Eur. J. Pharmacol. 2016, 785, 44-49. [CrossRef] [PubMed]

88. Alvarez-Curto, E.; Milligan, G. Metabolism meets immunity: The role of free fatty acid receptors in the immune system. Biochem. Pharmacol. 2016, 114, 3-13. [CrossRef]

89. Oh, D.Y.; Talukdar, S.; Bae, E.J.; Imamura, T.; Morinaga, H.; Fan, W.; Li, P.; Lu, W.J.; Watkins, S.M.; Olefsky, J.M. GPR120 is an omega-3 fatty acid receptor mediating potent anti-inflammatory and insulin-sensitizing effects. Cell 2010, 142, 687-698. [CrossRef]

90. Oh, D.Y.; Walenta, E.; Akiyama, T.E.; Lagakos, W.S.; Lackey, D.; Pessentheiner, A.R.; Sasik, R.; Hah, N.; Chi, T.J.; Cox, J.M.; et al. A Gpr120-selective agonist improves insulin resistance and chronic inflammation in obese mice. Nat. Med. 2014, 20, 942-947. [CrossRef]

91. Simopoulos, A.P. An Increase in the Omega-6/Omega-3 Fatty Acid Ratio Increases the Risk for Obesity. Nutrients 2016, 8, 128. [CrossRef] [PubMed]

92. Harris, W.S. The Omega-6:Omega-3 ratio: A critical appraisal and possible successor. Prostaglandins. Leukot. Essent. Fatty Acids 2018, 132, 34-40. [CrossRef] [PubMed]

93. Sibille, K.T.; King, C.; Garrett, T.J.; Glover, T.L.; Zhang, H.; Chen, H.; Reddy, D.; Goodin, B.R.; Sotolongo, A.; Petrov, M.E.; et al. Omega-6: Omega-3 PUFA Ratio, Pain, Functioning, and Distress in Adults With Knee Pain. Clin. J. Pain 2018, 34, 182-189. [CrossRef] 
94. Murphy, A.M.; Lyons, C.L.; Finucane, O.M.; Roche, H.M. Interactions between differential fatty acids and inflammatory stressorsimpact on metabolic health. Prostaglandins. Leukot. Essent. Fatty Acids 2015, 92, 49-55. [CrossRef]

95. Chan, K.L.; Pillon, N.J.; Sivaloganathan, D.M.; Costford, S.R.; Liu, Z.; Théret, M.; Chazaud, B.; Klip, A. Palmitoleate Reverses High Fat-induced Proinflammatory Macrophage Polarization via AMP-activated Protein Kinase (AMPK). J. Biol. Chem. 2015, 290, 16979-16988. [CrossRef]

96. Hwang, D.H.; Kim, J.-A.; Lee, J.Y. Mechanisms for the activation of Toll-like receptor $2 / 4$ by saturated fatty acids and inhibition by docosahexaenoic acid. Eur. J. Pharmacol. 2016, 785, 24-35. [CrossRef]

97. Li, B.; Leung, J.C.K.; Chan, L.Y.Y.; Yiu, W.H.; Tang, S.C.W. A global perspective on the crosstalk between saturated fatty acids and Toll-like receptor 4 in the etiology of inflammation and insulin resistance. Prog. Lipid Res. 2020, 77, 101020. [CrossRef]

98. Suganami, T.; Ogawa, Y. Adipose tissue macrophages: Their role in adipose tissue remodeling. J. Leukoc. Biol. 2010, 88, 33-39. [CrossRef]

99. Dasu, M.R.; Jialal, I. Free fatty acids in the presence of high glucose amplify monocyte inflammation via Toll-like receptors. Am. J. Physiol. Endocrinol. Metab. 2011, 300, E145-E154. [CrossRef]

100. Tsutsui, H.; Imamura, M.; Fujimoto, J.; Nakanishi, K. The TLR4/TRIF-Mediated Activation of NLRP3 Inflammasome Underlies Endotoxin-Induced Liver Injury in Mice. Gastroenterol. Res. Pract. 2010, 2010, 641865. [CrossRef] [PubMed]

101. Lyons, C.L.; Kennedy, E.B.; Roche, H.M. Metabolic Inflammation-Differential Modulation by Dietary Constituents. Nutrients 2016, 8, 247. [CrossRef]

102. De Boer, A.A.; Monk, J.M.; Liddle, D.M.; Hutchinson, A.L.; Power, K.A.; Ma, D.W.L.; Robinson, L.E. Fish-oil-derived n3 polyunsaturated fatty acids reduce NLRP3 inflammasome activity and obesity-related inflammatory cross-talk between adipocytes and CD11b(+) macrophages. J. Nutr. Biochem. 2016, 34, 61-72. [CrossRef]

103. He, J.; Zhang, P.; Shen, L.; Niu, L.; Tan, Y.; Chen, L.; Zhao, Y.; Bai, L.; Hao, X.; Li, X.; et al. Short-Chain Fatty Acids and Their Association with Signalling Pathways in Inflammation, Glucose and Lipid Metabolism. Int. J. Mol. Sci. 2020, 21, 6356. [CrossRef]

104. Vinolo, M.A.R.; Rodrigues, H.G.; Hatanaka, E.; Sato, F.T.; Sampaio, S.C.; Curi, R. Suppressive effect of short-chain fatty acids on production of proinflammatory mediators by neutrophils. J. Nutr. Biochem. 2011, 22, 849-855. [CrossRef]

105. Aoyama, M.; Kotani, J.; Usami, M. Butyrate and propionate induced activated or non-activated neutrophil apoptosis via HDAC inhibitor activity but without activating GPR-41/GPR-43 pathways. Nutrition 2010, 26, 653-661. [CrossRef]

106. Vinolo, M.A.R.; Rodrigues, H.G.; Nachbar, R.T.; Curi, R. Regulation of inflammation by short chain fatty acids. Nutrients 2011, 3 , 858-876. [CrossRef] [PubMed]

107. Chang, P.V.; Hao, L.; Offermanns, S.; Medzhitov, R. The microbial metabolite butyrate regulates intestinal macrophage function via histone deacetylase inhibition. Proc. Natl. Acad. Sci. USA 2014, 111, 2247-2252. [CrossRef]

108. Kim, M.H.; Kang, S.G.; Park, J.H.; Yanagisawa, M.; Kim, C.H. Short-chain fatty acids activate GPR41 and GPR43 on intestinal epithelial cells to promote inflammatory responses in mice. Gastroenterology 2013, 145, 310-396. [CrossRef] [PubMed]

109. Mirmonsef, P.; Zariffard, M.R.; Gilbert, D.; Makinde, H.; Landay, A.L.; Spear, G.T. Short-chain fatty acids induce pro-inflammatory cytokine production alone and in combination with toll-like receptor ligands. Am. J. Reprod. Immunol. 2012, 67, 391-400. [CrossRef]

110. Mao, L.; Hochstetter, D.; Yao, L.; Zhao, Y.; Zhou, J.; Wang, Y.; Xu, P. Green Tea Polyphenol (-)-Epigallocatechin Gallate (EGCG) Attenuates Neuroinflammation in Palmitic Acid-Stimulated BV-2 Microglia and High-Fat Diet-Induced Obese Mice. Int. J. Mol. Sci. 2019, 20, 5081. [CrossRef]

111. Zhang, Y.-J.; Zhao, H.; Dong, L.; Zhen, Y.-F.; Xing, H.-Y.; Ma, H.-J.; Song, G.-Y. Resveratrol ameliorates high-fat diet-induced insulin resistance and fatty acid oxidation via ATM-AMPK axis in skeletal muscle. Eur. Rev. Med. Pharmacol. Sci. 2019, 23, 9117-9125. [CrossRef]

112. Tanaka, M.; Sato, A.; Kishimoto, Y.; Mabashi-Asazuma, H.; Kondo, K.; Iida, K. Gallic Acid Inhibits Lipid Accumulation via AMPK Pathway and Suppresses Apoptosis and Macrophage-Mediated Inflammation in Hepatocytes. Nutrients 2020, 12, 1479. [CrossRef]

113. Sokolova, M.; Yang, K.; Hansen, S.H.; Louwe, M.C.; Kummen, M.; Hov, J.E.R.; Sjaastad, I.; Berge, R.K.; Halvorsen, B.; Aukrust, P.; et al. NLRP3 inflammasome deficiency attenuates metabolic disturbances involving alterations in the gut microbial profile in mice exposed to high fat diet. Sci. Rep. 2020, 10, 21006. [CrossRef]

114. Herbert, D.; Franz, S.; Popkova, Y.; Anderegg, U.; Schiller, J.; Schwede, K.; Lorz, A.; Simon, J.C.; Saalbach, A. High-Fat Diet Exacerbates Early Psoriatic Skin Inflammation Independent of Obesity: Saturated Fatty Acids as Key Players. J. Investig. Dermatol. 2018, 138, 1999-2009. [CrossRef]

115. Hernández, E.Á.; Kahl, S.; Seelig, A.; Begovatz, P.; Irmler, M.; Kupriyanova, Y.; Nowotny, B.; Nowotny, P.; Herder, C.; Barosa, C.; et al. Acute dietary fat intake initiates alterations in energy metabolism and insulin resistance. J. Clin. Investig. 2017, 127, 695-708. [CrossRef]

116. Russo, S.B.; Baicu, C.F.; Van Laer, A.; Geng, T.; Kasiganesan, H.; Zile, M.R.; Cowart, L.A. Ceramide synthase 5 mediates lipid-induced autophagy and hypertrophy in cardiomyocytes. J. Clin. Investig. 2012, 122, 3919-3930. [CrossRef]

117. Muthuramu, I.; Amin, R.; Postnov, A.; Mishra, M.; Jacobs, F.; Gheysens, O.; Van Veldhoven, P.P.; De Geest, B. Coconut Oil Aggravates Pressure Overload-Induced Cardiomyopathy without Inducing Obesity, Systemic Insulin Resistance, or Cardiac Steatosis. Int. J. Mol. Sci. 2017, 18, 1565. [CrossRef] [PubMed] 
118. Pistell, P.J.; Morrison, C.D.; Gupta, S.; Knight, A.G.; Keller, J.N.; Ingram, D.K.; Bruce-Keller, A.J. Cognitive impairment following high fat diet consumption is associated with brain inflammation. J. Neuroimmunol. 2010, 219, 25-32. [CrossRef]

119. Ralston, J.C.; Nguyen-Tu, M.-S.; Lyons, C.L.; Cooke, A.A.; Murphy, A.M.; Falvey, A.; Finucane, O.M.; McGillicuddy, F.C.; Rutter, G.A.; Roche, H.M. Dietary substitution of SFA with MUFA within high-fat diets attenuates hyperinsulinaemia and pancreatic islet dysfunction. Br. J. Nutr. 2020, 124, 247-255. [CrossRef] [PubMed]

120. McLean, F.H.; Campbell, F.M.; Sergi, D.; Grant, C.; Morris, A.C.; Hay, E.A.; MacKenzie, A.; Mayer, C.D.; Langston, R.F.; Williams, L.M. Early and reversible changes to the hippocampal proteome in mice on a high-fat diet. Nutr. Metab. 2019, 16, 57. [CrossRef] [PubMed]

121. Macartney, M.J.; Peoples, G.E.; McLennan, P.L. Cardiac Arrhythmia Prevention in Ischemia and Reperfusion by Low-Dose Dietary Fish Oil Supplementation in Rats. J. Nutr. 2020, 150, 3086-3093. [CrossRef]

122. Ding, L.; Zhang, L.; Wen, M.; Che, H.; Du, L.; Wang, J.; Xue, C.; Xu, J.; Wang, Y. Eicosapentaenoic acid-enriched phospholipids improve atherosclerosis by mediating cholesterol metabolism. J. Funct. Foods 2017, 32, 90-97. [CrossRef]

123. Zhang, L.-Y.; Ding, L.; Shi, H.-H.; Xu, J.; Xue, C.-H.; Zhang, T.-T.; Wang, Y.-M. Eicosapentaenoic acid in the form of phospholipids exerts superior anti-atherosclerosis effects to its triglyceride form in ApoE(-/-) mice. Food Funct. 2019, 10, 4177-4188. [CrossRef]

124. Wang, R.; Chai, Q.; Lu, T.; Lee, H.-C. Activation of vascular BK channels by docosahexaenoic acid is dependent on cytochrome P450 epoxygenase activity. Cardiovasc. Res. 2011, 90, 344-352. [CrossRef]

125. Börjesson, S.I.; Elinder, F. An electrostatic potassium channel opener targeting the final voltage sensor transition. J. Gen. Physiol. 2011, 137, 563-577. [CrossRef]

126. Takashima, A.; Fukuda, D.; Tanaka, K.; Higashikuni, Y.; Hirata, Y.; Nishimoto, S.; Yagi, S.; Yamada, H.; Soeki, T.; Wakatsuki, T.; et al. Combination of $\mathrm{n}-3$ polyunsaturated fatty acids reduces atherogenesis in apolipoprotein E-deficient mice by inhibiting macrophage activation. Atherosclerosis 2016, 254, 142-150. [CrossRef]

127. Chang, C.L.; Torrejon, C.; Jung, U.J.; Graf, K.; Deckelbaum, R.J. Incremental replacement of saturated fats by n-3 fatty acids in highfat, high-cholesterol diets reduces elevated plasma lipid levels and arterial lipoprotein lipase, macrophages and atherosclerosis in LDLR-/- mice. Atherosclerosis 2014, 234, 401-409. [CrossRef]

128. Deyama, S.; Ishikawa, Y.; Yoshikawa, K.; Shimoda, K.; Ide, S.; Satoh, M.; Minami, M. Resolvin D1 and D2 Reverse Lipopolysaccharide-Induced Depression-Like Behaviors Through the mTORC1 Signaling Pathway. Int. J. Neuropsychopharmacol. 2017, 20, 575-584. [CrossRef]

129. Wen, M.; Xu, J.; Ding, L.; Zhang, L.; Du, L.; Wang, J.; Wang, Y.; Xue, C. Eicosapentaenoic acid-enriched phospholipids improve A $\beta 1-40$-induced cognitive deficiency in a rat model of Alzheimer's disease. J. Funct. Foods 2016, 24, 537-548. [CrossRef]

130. Liao, K.; Yan, J.; Mai, K.; Ai, Q. Dietary Olive and Perilla Oils Affect Liver Mitochondrial DNA Methylation in Large Yellow Croakers. J. Nutr. 2015, 145, 2479-2485. [CrossRef]

131. Boddicker, R.L.; Koltes, J.E.; Fritz-Waters, E.R.; Koesterke, L.; Weeks, N.; Yin, T.; Mani, V.; Nettleton, D.; Reecy, J.M.; Baumgard, L.H.; et al. Genome-wide methylation profile following prenatal and postnatal dietary omega-3 fatty acid supplementation in pigs. Anim. Genet. 2016, 47, 658-671. [CrossRef] [PubMed]

132. Huang, Q.; Wen, J.; Chen, G.; Ge, M.; Gao, Y.; Ye, X.; Liu, C.; Cai, C. Omega-3 Polyunsaturated Fatty Acids Inhibited Tumor Growth via Preventing the Decrease of Genomic DNA Methylation in Colorectal Cancer Rats. Nutr. Cancer 2016, 68, 113-119. [CrossRef]

133. Lomba, A.; Martínez, J.A.; García-Díaz, D.F.; Paternain, L.; Marti, A.; Campión, J.; Milagro, F.I. Weight gain induced by an isocaloric pair-fed high fat diet: A nutriepigenetic study on FASN and NDUFB6 gene promoters. Mol. Genet. Metab. 2010, 101, 273-278. [CrossRef]

134. Samblas, M.; Carraro, J.C.; Martínez, J.A.; Milagro, F.I. The regulation of inflammation-related genes after palmitic acid and DHA treatments is not mediated by DNA methylation. J. Physiol. Biochem. 2019, 75, 341-349. [CrossRef]

135. Cordero, P.; Campion, J.; Milagro, F.I.; Martinez, J.A. Transcriptomic and epigenetic changes in early liver steatosis associated to obesity: Effect of dietary methyl donor supplementation. Mol. Genet. Metab. 2013, 110, 388-395. [CrossRef]

136. Uriarte, G.; Paternain, L.; Milagro, F.I.; Martínez, J.A.; Campion, J. Shifting to a control diet after a high-fat, high-sucrose diet intake induces epigenetic changes in retroperitoneal adipocytes of Wistar rats. J. Physiol. Biochem. 2013, 69, 601-611. [CrossRef] [PubMed]

137. Lottenberg, A.M.; Afonso, M.d.S.; Lavrador, M.S.F.; Machado, R.M.; Nakandakare, E.R. The role of dietary fatty acids in the pathology of metabolic syndrome. J. Nutr. Biochem. 2012, 23, 1027-1040. [CrossRef]

138. Rodríguez-Cruz, M.; Serna, D.S. Nutrigenomics of $\omega-3$ fatty acids: Regulators of the master transcription factors. Nutrition 2017, 41, 90-96. [CrossRef]

139. Naeini, Z.; Toupchian, O.; Vatannejad, A.; Sotoudeh, G.; Teimouri, M.; Ghorbani, M.; Nasli-Esfahani, E.; Koohdani, F. Effects of DHA-enriched fish oil on gene expression levels of p53 and NF- $\mathrm{kB}$ and PPAR- $\gamma$ activity in PBMCs of patients with T2DM: A randomized, double-blind, clinical trial. Nutr. Metab. Cardiovasc. Dis. 2020, 30, 441-447. [CrossRef]

140. Jamilian, M.; Tabassi, Z.; Reiner, Ž.; Panahandeh, I.; Naderi, F.; Aghadavod, E.; Amirani, E.; Taghizadeh, M.; Shafabakhsh, R.; Satari, M.; et al. The effects of n-3 fatty acids from flaxseed oil on genetic and metabolic profiles in patients with gestational diabetes mellitus: A randomised, double-blind, placebo-controlled trial. Br. J. Nutr. 2020, 123, 792-799. [CrossRef] 
141. Golpour, P.; Nourbakhsh, M.; Mazaherioun, M.; Janani, L.; Nourbakhsh, M.; Yaghmaei, P. Improvement of NRF2 gene expression and antioxidant status in patients with type 2 diabetes mellitus after supplementation with omega-3 polyunsaturated fatty acids: A double-blind randomised placebo-controlled clinical trial. Diabetes Res. Clin. Pract. 2020, 162, 108120. [CrossRef]

142. Ma, Q. Role of nrf2 in oxidative stress and toxicity. Annu. Rev. Pharmacol. Toxicol. 2013, 53, 401-426. [CrossRef] [PubMed]

143. Tamtaji, O.R.; Taghizadeh, M.; Aghadavod, E.; Mafi, A.; Dadgostar, E.; Daneshvar Kakhaki, R.; Abolhassani, J.; Asemi, Z. The effects of omega-3 fatty acids and vitamin E co-supplementation on gene expression related to inflammation, insulin and lipid in patients with Parkinson's disease: A randomized, double-blind, placebo-controlled trial. Clin. Neurol. Neurosurg. 2019, 176, 116-121. [CrossRef] [PubMed]

144. Jamilian, M.; Samimi, M.; Mirhosseini, N.; Afshar Ebrahimi, F.; Aghadavod, E.; Talaee, R.; Jafarnejad, S.; Hashemi Dizaji, S.; Asemi, Z. The influences of vitamin D and omega-3 co-supplementation on clinical, metabolic and genetic parameters in women with polycystic ovary syndrome. J. Affect. Disord. 2018, 238, 32-38. [CrossRef]

145. Larsen, S.V.; Holven, K.B.; Ottestad, I.; Dagsland, K.N.; Myhrstad, M.C.W.; Ulven, S.M. Plasma fatty acid levels and gene expression related to lipid metabolism in peripheral blood mononuclear cells: A cross-sectional study in healthy subjects. Genes Nutr. 2018, 13, 9. [CrossRef] [PubMed]

146. Matualatupauw, J.C.; Bohl, M.; Gregersen, S.; Hermansen, K.; Afman, L.A. Dietary medium-chain saturated fatty acids induce gene expression of energy metabolism-related pathways in adipose tissue of abdominally obese subjects. Int. J. Obes. 2017, 41, 1348-1354. [CrossRef]

147. Ulven, S.M.; Christensen, J.J.; Nygård, O.; Svardal, A.; Leder, L.; Ottestad, I.; Lysne, V.; Laupsa-Borge, J.; Ueland, P.M.; Midttun, $\varnothing$.; et al. Using metabolic profiling and gene expression analyses to explore molecular effects of replacing saturated fat with polyunsaturated fat-a randomized controlled dietary intervention study. Am. J. Clin. Nutr. 2019, 109, 1239-1250. [CrossRef]

148. Castañer, O.; Corella, D.; Covas, M.-I.; Sorlí, J.V.; Subirana, I.; Flores-Mateo, G.; Nonell, L.; Bulló, M.; de la Torre, R.; Portolés, O.; et al. In vivo transcriptomic profile after a Mediterranean diet in high-cardiovascular risk patients: A randomized controlled trial. Am. J. Clin. Nutr. 2013, 98, 845-853. [CrossRef]

149. Camargo, A.; Delgado-Lista, J.; Garcia-Rios, A.; Cruz-Teno, C.; Yubero-Serrano, E.M.; Perez-Martinez, P.; Gutierrez-Mariscal, F.M.; Lora-Aguilar, P.; Rodriguez-Cantalejo, F.; Fuentes-Jimenez, F.; et al. Expression of proinflammatory, proatherogenic genes is reduced by the Mediterranean diet in elderly people. Br. J. Nutr. 2012, 108, 500-508. [CrossRef]

150. Perrone, M.A.; Gualtieri, P.; Gratteri, S.; Ali, W.; Sergi, D.; Muscoli, S.; Cammarano, A.; Bernardini, S.; Di Renzo, L.; Romeo, F. Effects of postprandial hydroxytyrosol and derivates on oxidation of LDL, cardiometabolic state and gene expression: A nutrigenomic approach for cardiovascular prevention. J. Cardiovasc. Med. 2019, 20, 419-426. [CrossRef]

151. Farràs, M.; Arranz, S.; Carrión, S.; Subirana, I.; Muñoz-Aguayo, D.; Blanchart, G.; Kool, M.; Solà, R.; Motilva, M.J.; Escolà-Gil, J.C.; et al. A Functional Virgin Olive Oil Enriched with Olive Oil and Thyme Phenolic Compounds Improves the Expression of Cholesterol Efflux-Related Genes: A Randomized, Crossover, Controlled Trial. Nutrients 2019, 11, 1732. [CrossRef]

152. Arpón, A.; Milagro, F.I.; Razquin, C.; Corella, D.; Estruch, R.; Fitó, M.; Marti, A.; Martínez-González, M.A.; Ros, E.; Salas-Salvadó, J.; et al. Impact of Consuming Extra-Virgin Olive Oil or Nuts within a Mediterranean Diet on DNA Methylation in Peripheral White Blood Cells within the PREDIMED-Navarra Randomized Controlled Trial: A Role for Dietary Lipids. Nutrients 2017, 10, 15. [CrossRef]

153. González-Becerra, K.; Ramos-Lopez, O.; Barrón-Cabrera, E.; Riezu-Boj, J.I.; Milagro, F.I.; Martínez-López, E.; Martínez, J.A. Fatty acids, epigenetic mechanisms and chronic diseases: A systematic review. Lipids Health Dis. 2019, 18, 178. [CrossRef]

154. Ghadge, A.A.; Khaire, A.A.; Kuvalekar, A.A. Adiponectin: A potential therapeutic target for metabolic syndrome. Cytokine Growth Factor Rev. 2018, 39, 151-158. [CrossRef]

155. Maintinguer Norde, M.; Oki, É.; de Castro, I.A.; Pacheco Souza, J.M.; Teixeira Damasceno, N.R.; Mara Fisberg, R.; Lobo Marchioni, D.M.; Macedo Rogero, M. Influence of adiponectin gene variants and plasma fatty acids on systemic inflammation state association-A cross-sectional population-based study, São Paulo, Brazil. Mol. Nutr. Food Res. 2016, 60, 278-286. [CrossRef]

156. Alsaleh, A.; Crepostnaia, D.; Maniou, Z.; Lewis, F.J.; Hall, W.L.; Sanders, T.A.B.; O’Dell, S.D. Adiponectin gene variant interacts with fish oil supplementation to influence serum adiponectin in older individuals. J. Nutr. 2013, 143, 1021-1027. [CrossRef]

157. AlSaleh, A.; O’Dell, S.D.; Frost, G.S.; Griffin, B.A.; Lovegrove, J.A.; Jebb, S.A.; Sanders, T.A.B. Single nucleotide polymorphisms at the ADIPOQ gene locus interact with age and dietary intake of fat to determine serum adiponectin in subjects at risk of the metabolic syndrome. Am. J. Clin. Nutr. 2011, 94, 262-269. [CrossRef]

158. Marais, A.D. Apolipoprotein E in lipoprotein metabolism, health and cardiovascular disease. Pathology 2019, 51, 165-176. [CrossRef]

159. Ordovas, J.M.; Corella, D. Genetic variation and lipid metabolism: Modulation by dietary factors. Curr. Cardiol. Rep. 2005, 7, 480-486. [CrossRef]

160. Corella, D.; Ordovás, J.M. Aging and cardiovascular diseases: The role of gene-diet interactions. Ageing Res. Rev. 2014, 18, 53-73. [CrossRef]

161. Fallaize, R.; Celis-Morales, C.; Macready, A.L.; Marsaux, C.F.; Forster, H.; O’Donovan, C.; Woolhead, C.; San-Cristobal, R.; Kolossa, S.; Hallmann, J.; et al. The effect of the apolipoprotein $\mathrm{E}$ genotype on response to personalized dietary advice intervention: Findings from the Food4Me randomized controlled trial. Am. J. Clin. Nutr. 2016, 104, 827-836. [CrossRef]

162. Carvalho-Wells, A.L.; Jackson, K.G.; Lockyer, S.; Lovegrove, J.A.; Minihane, A.M. APOE genotype influences triglyceride and C-reactive protein responses to altered dietary fat intake in UK adults. Am. J. Clin. Nutr. 2012, 96, 1447-1453. [CrossRef] [PubMed] 
163. Rathnayake, K.M.; Weech, M.; Jackson, K.G.; Lovegrove, J.A. Impact of the Apolipoprotein E (epsilon) Genotype on Cardiometabolic Risk Markers and Responsiveness to Acute and Chronic Dietary Fat Manipulation. Nutrients 2019, 11, 2044. [CrossRef]

164. Kettunen, T.; Eklund, C.; Kähönen, M.; Jula, A.; Päivä, H.; Lyytikäinen, L.-P.; Hurme, M.; Lehtimäki, T. Polymorphism in the C-reactive protein (CRP) gene affects CRP levels in plasma and one early marker of atherosclerosis in men: The Health 2000 Survey. Scand. J. Clin. Lab. Investig. 2011, 71, 353-361. [CrossRef]

165. Nienaber-Rousseau, C.; Swanepoel, B.; Dolman, R.C.; Pieters, M.; Conradie, K.R.; Towers, G.W. Interactions between C-reactive protein genotypes with markers of nutritional status in relation to inflammation. Nutrients 2014, 6, 5034-5050. [CrossRef] [PubMed]

166. Arouca, A.B.; Meirhaeghe, A.; Dallongeville, J.; Moreno, L.A.; Lourenço, G.J.; Marcos, A.; Huybrechts, I.; Manios, Y.; Lambrinou, C.-P.; Gottrand, F.; et al. Interplay between the Mediterranean diet and C-reactive protein genetic polymorphisms towards inflammation in adolescents. Clin. Nutr. 2020, 39, 1919-1926. [CrossRef] [PubMed]

167. Muka, T.; Kiefte-de Jong, J.C.; Hofman, A.; Dehghan, A.; Rivadeneira, F.; Franco, O.H. Polyunsaturated fatty acids and serum C-reactive protein: The Rotterdam study. Am. J. Epidemiol. 2015, 181, 846-856. [CrossRef] [PubMed]

168. Oki, E.; Norde, M.M.; Carioca, A.A.F.; Ikeda, R.E.; Souza, J.M.P.; Castro, I.A.; Marchioni, D.M.L.; Fisberg, R.M.; Rogero, M.M. Interaction of SNP in the CRP gene and plasma fatty acid profile in inflammatory pattern: A cross-sectional population-based study. Nutrition 2016, 32, 88-94. [CrossRef] [PubMed]

169. Koletzko, B.; Reischl, E.; Tanjung, C.; Gonzalez-Casanova, I.; Ramakrishnan, U.; Meldrum, S.; Simmer, K.; Heinrich, J.; Demmelmair, H. FADS1 and FADS2 Polymorphisms Modulate Fatty Acid Metabolism and Dietary Impact on Health. Annu. Rev. Nutr. 2019, 39, 21-44. [CrossRef]

170. Brayner, B.; Kaur, G.; Keske, M.A.; Livingstone, K.M. FADS Polymorphism, Omega-3 Fatty Acids and Diabetes Risk: A Systematic Review. Nutrients 2018, 10, 758. [CrossRef]

171. Ameur, A.; Enroth, S.; Johansson, A.; Zaboli, G.; Igl, W.; Johansson, A.C.V.; Rivas, M.A.; Daly, M.J.; Schmitz, G.; Hicks, A.A.; et al. Genetic adaptation of fatty-acid metabolism: A human-specific haplotype increasing the biosynthesis of long-chain omega-3 and omega-6 fatty acids. Am. J. Hum. Genet. 2012, 90, 809-820. [CrossRef]

172. Hester, A.G.; Murphy, R.C.; Uhlson, C.J.; Ivester, P.; Lee, T.C.; Sergeant, S.; Miller, L.R.; Howard, T.D.; Mathias, R.A.; Chilton, F.H. Relationship between a common variant in the fatty acid desaturase (FADS) cluster and eicosanoid generation in humans. J. Biol. Chem. 2014, 289, 22482-22489. [CrossRef] [PubMed]

173. Kim, O.Y.; Lim, H.H.; Yang, L.I.; Chae, J.S.; Lee, J.H. Fatty acid desaturase (FADS) gene polymorphisms and insulin resistance in association with serum phospholipid polyunsaturated fatty acid composition in healthy Korean men: Cross-sectional study. Nutr. Metab. 2011, 8, 24. [CrossRef]

174. Klingel, S.L.; Valsesia, A.; Astrup, A.; Kunesova, M.; Saris, W.H.M.; Langin, D.; Viguerie, N.; Mutch, D.M. FADS1 genotype is distinguished by human subcutaneous adipose tissue fatty acids, but not inflammatory gene expression. Int. J. Obes. 2019, 43, 1539-1548. [CrossRef] [PubMed]

175. Lankinen, M.A.; Fauland, A.; Shimizu, B.-I.; Ågren, J.; Wheelock, C.E.; Laakso, M.; Schwab, U.; Pihlajamäki, J. Inflammatory response to dietary linoleic acid depends on FADS1 genotype. Am. J. Clin. Nutr. 2019, 109, 165-175. [CrossRef]

176. Mullins, V.A.; Bresette, W.; Johnstone, L.; Hallmark, B.; Chilton, F.H. Genomics in Personalized Nutrition: Can You “Eat for Your Genes"? Nutrients 2020, 12, 3118. [CrossRef]

177. Rudkowska, I.; Guénard, F.; Julien, P.; Couture, P.; Lemieux, S.; Barbier, O.; Calder, P.C.; Minihane, A.M.; Vohl, M.-C. Genomewide association study of the plasma triglyceride response to an $\mathrm{n}-3$ polyunsaturated fatty acid supplementation. J. Lipid Res. 2014, 55, 1245-1253. [CrossRef]

178. Ramos-Lopez, O.; Milagro, F.I.; Allayee, H.; Chmurzynska, A.; Choi, M.S.; Curi, R.; De Caterina, R.; Ferguson, L.R.; Goni, L.; Kang, J.X.; et al. Guide for Current Nutrigenetic, Nutrigenomic, and Nutriepigenetic Approaches for Precision Nutrition Involving the Prevention and Management of Chronic Diseases Associated with Obesity. J. Nutrigenet. Nutr. 2017, 10, 43-62. [CrossRef]

179. Ferguson, L.R.; De Caterina, R.; Görman, U.; Allayee, H.; Kohlmeier, M.; Prasad, C.; Choi, M.S.; Curi, R.; de Luis, D.A.; Gil, Á.; et al. Guide and Position of the International Society of Nutrigenetics/Nutrigenomics on Personalised Nutrition: Part 1-Fields of Precision Nutrition. J. Nutrigenet. Nutr. 2016, 9, 12-27. [CrossRef]

180. Martinez-Guryn, K.; Leone, V.; Chang, E.B. Regional Diversity of the Gastrointestinal Microbiome. Cell Host Microbe 2019, 26, 314-324. [CrossRef]

181. Rinninella, E.; Raoul, P.; Cintoni, M.; Franceschi, F.; Miggiano, G.A.D.; Gasbarrini, A.; Mele, M.C. What is the Healthy Gut Microbiota Composition? A Changing Ecosystem across Age, Environment, Diet, and Diseases. Microorganisms $2019,7,14$. [CrossRef] [PubMed]

182. Rinninella, E.; Cintoni, M.; Raoul, P.; Lopetuso, L.R.; Scaldaferri, F.; Pulcini, G.; Miggiano, G.A.D.; Gasbarrini, A.; Mele, M.C. Food Components and Dietary Habits: Keys for a Healthy Gut Microbiota Composition. Nutrients 2019, 11, 2393. [CrossRef] [PubMed]

183. Agans, R.; Gordon, A.; Kramer, D.L.; Perez-Burillo, S.; Rufián-Henares, J.A.; Paliy, O. Dietary Fatty Acids Sustain the Growth of the Human Gut Microbiota. Appl. Environ. Microbiol. 2018, 84, e01525-18. [CrossRef] [PubMed]

184. Jackman, J.A.; Yoon, B.K.; Li, D.; Cho, N.-J. Nanotechnology Formulations for Antibacterial Free Fatty Acids and Monoglycerides. Molecules 2016, 21, 305. [CrossRef] [PubMed] 
185. Yao, J.; Rock, C.O. Exogenous fatty acid metabolism in bacteria. Biochimie 2017, 141, 30-39. [CrossRef]

186. Crovesy, L.; Masterson, D.; Rosado, E.L. Profile of the gut microbiota of adults with obesity: A systematic review. Eur. J. Clin. Nutr. 2020, 74, 1251-1262. [CrossRef] [PubMed]

187. Hidalgo-Cantabrana, C.; Delgado, S.; Ruiz, L.; Ruas-Madiedo, P.; Sánchez, B.; Margolles, A. Bifidobacteria and Their HealthPromoting Effects. Microbiol. Spectr. 2017, 5, 5-3. [CrossRef]

188. Kiu, R.; Hall, L.J. An update on the human and animal enteric pathogen Clostridium perfringens. Emerg. Microbes Infect. 2018, 7, 141. [CrossRef]

189. Natividad, J.M.; Lamas, B.; Pham, H.P.; Michel, M.-L.; Rainteau, D.; Bridonneau, C.; da Costa, G.; van Hylckama Vlieg, J.; Sovran, B.; Chamignon, C.; et al. Bilophila wadsworthia aggravates high fat diet induced metabolic dysfunctions in mice. Nat. Commun. 2018, 9, 2802. [CrossRef]

190. Fu, X.; Liu, Z.; Zhu, C.; Mou, H.; Kong, Q. Nondigestible carbohydrates, butyrate, and butyrate-producing bacteria. Crit. Rev. Food Sci. Nutr. 2019, 59, S130-S152. [CrossRef]

191. Kim, K.-A.; Gu, W.; Lee, I.-A.; Joh, E.-H.; Kim, D.-H. High fat diet-induced gut microbiota exacerbates inflammation and obesity in mice via the TLR4 signaling pathway. PLoS ONE 2012, 7, e47713. [CrossRef] [PubMed]

192. Lam, Y.Y.; Ha, C.W.Y.; Hoffmann, J.M.A.; Oscarsson, J.; Dinudom, A.; Mather, T.J.; Cook, D.I.; Hunt, N.H.; Caterson, I.D.; Holmes, A.J.; et al. Effects of dietary fat profile on gut permeability and microbiota and their relationships with metabolic changes in mice. Obesity 2015, 23, 1429-1439. [CrossRef]

193. Huang, E.Y.; Leone, V.A.; Devkota, S.; Wang, Y.; Brady, M.J.; Chang, E.B. Composition of dietary fat source shapes gut microbiota architecture and alters host inflammatory mediators in mouse adipose tissue. JPEN J. Parenter. Enter. Nutr. 2013, 37, 746-754. [CrossRef] [PubMed]

194. Djurasevic, S.; Bojic, S.; Nikolic, B.; Dimkic, I.; Todorovic, Z.; Djordjevic, J.; Mitic-Culafic, D. Beneficial Effect of Virgin Coconut Oil on Alloxan-Induced Diabetes and Microbiota Composition in Rats. Plant Foods Hum. Nutr. 2018, 73, 295-301. [CrossRef] [PubMed]

195. Zhou, S.; Wang, Y.; Jacoby, J.J.; Jiang, Y.; Zhang, Y.; Yu, L.L. Effects of Medium- and Long-Chain Triacylglycerols on Lipid Metabolism and Gut Microbiota Composition in C57BL/6J Mice. J. Agric. Food Chem. 2017, 65, 6599-6607. [CrossRef]

196. de Souza, R.J.; Mente, A.; Maroleanu, A.; Cozma, A.I.; Ha, V.; Kishibe, T.; Uleryk, E.; Budylowski, P.; Schünemann, H.; Beyene, J.; et al. Intake of saturated and trans unsaturated fatty acids and risk of all cause mortality, cardiovascular disease, and type 2 diabetes: Systematic review and meta-analysis of observational studies. BMJ 2015, 351, h3978. [CrossRef]

197. Ge, Y.; Liu, W.; Tao, H.; Zhang, Y.; Liu, L.; Liu, Z.; Qiu, B.; Xu, T. Effect of industrial trans-fatty acids-enriched diet on gut microbiota of C57BL/ 6 mice. Eur. J. Nutr. 2019, 58, 2625-2638. [CrossRef]

198. Hua, Y.; Fan, R.; Zhao, L.; Tong, C.; Qian, X.; Zhang, M.; Xiao, R.; Ma, W. Trans-fatty acids alter the gut microbiota in high-fat-dietinduced obese rats. Br. J. Nutr. 2020, 124, 1251-1263. [CrossRef]

199. Shin, N.-R.; Whon, T.W.; Bae, J.-W. Proteobacteria: Microbial signature of dysbiosis in gut microbiota. Trends Biotechnol. 2015, 33, 496-503. [CrossRef] [PubMed]

200. Patterson, E.; O’ Doherty, R.M.; Murphy, E.F.; Wall, R.; O' Sullivan, O.; Nilaweera, K.; Fitzgerald, G.F.; Cotter, P.D.; Ross, R.P.; Stanton, C. Impact of dietary fatty acids on metabolic activity and host intestinal microbiota composition in C57BL/6J mice. Br. J. Nutr. 2014, 111, 1905-1917. [CrossRef]

201. Yu, H.-N.; Zhu, J.; Pan, W.; Shen, S.-R.; Shan, W.-G.; Das, U.N. Effects of fish oil with a high content of n-3 polyunsaturated fatty acids on mouse gut microbiota. Arch. Med. Res. 2014, 45, 195-202. [CrossRef]

202. Ghosh, S.; DeCoffe, D.; Brown, K.; Rajendiran, E.; Estaki, M.; Dai, C.; Yip, A.; Gibson, D.L. Fish oil attenuates omega-6 polyunsaturated fatty acid-induced dysbiosis and infectious colitis but impairs LPS dephosphorylation activity causing sepsis. PLoS ONE 2013, 8, e55468. [CrossRef]

203. Robertson, R.C.; Seira Oriach, C.; Murphy, K.; Moloney, G.M.; Cryan, J.F.; Dinan, T.G.; Paul Ross, R.; Stanton, C. Omega-3 polyunsaturated fatty acids critically regulate behaviour and gut microbiota development in adolescence and adulthood. Brain. Behav. Immun. 2017, 59, 21-37. [CrossRef]

204. Patrone, V.; Ferrari, S.; Lizier, M.; Lucchini, F.; Minuti, A.; Tondelli, B.; Trevisi, E.; Rossi, F.; Callegari, M.L. Short-term modifications in the distal gut microbiota of weaning mice induced by a high-fat diet. Microbiology 2012, 158, 983-992. [CrossRef]

205. Wolters, M.; Ahrens, J.; Romaní-Pérez, M.; Watkins, C.; Sanz, Y.; Benítez-Páez, A.; Stanton, C.; Günther, K. Dietary fat, the gut microbiota, and metabolic health-A systematic review conducted within the MyNewGut project. Clin. Nutr. 2019, 38, 2504-2520. [CrossRef]

206. Etxeberria, U.; Arias, N.; Boqué, N.; Macarulla, M.T.; Portillo, M.P.; Milagro, F.I.; Martinez, J.A. Shifts in microbiota species and fermentation products in a dietary model enriched in fat and sucrose. Benef. Microbes 2015, 6, 97-111. [CrossRef]

207. Etxeberria, U.; Arias, N.; Boqué, N.; Macarulla, M.T.; Portillo, M.P.; Martínez, J.A.; Milagro, F.I. Reshaping faecal gut microbiota composition by the intake of trans-resveratrol and quercetin in high-fat sucrose diet-fed rats. J. Nutr. Biochem. 2015, 26, 651-660. [CrossRef]

208. Cuevas-Sierra, A.; Ramos-Lopez, O.; Riezu-Boj, J.I.; Milagro, F.I.; Martinez, J.A. Diet, Gut Microbiota, and Obesity: Links with Host Genetics and Epigenetics and Potential Applications. Adv. Nutr. 2019, 10, S17-S30. [CrossRef] 
209. Mazidi, M.; Katsiki, N.; Shekoohi, N.; Banach, M. Monounsaturated Fatty Acid Levels May Not Affect Cardiovascular Events: Results From a Mendelian Randomization Analysis. Front. Nutr. 2020, 7, 123. [CrossRef]

210. Parchem, K.; Sasson, S.; Ferreri, C.; Bartoszek, A. Qualitative analysis of phospholipids and their oxidised derivatives-Used techniques and examples of their applications related to lipidomic research and food analysis. Free Radic. Res. 2019, 53, 1068-1100. [CrossRef] 